\title{
St. Vincent and the Grenadines-Request for Disbursement Under the Rapid Credit Facility
}

The following documents have been released and are included in this package:

- $\quad$ The staff report, prepared by a staff team of the IMF, following discussions that ended on January 11, 2011 with the officials of St. Vincent and the Grenadines on economic developments and policies. Based on information available at the time of these discussions, the staff report was completed on February 16, 2011. The views expressed in the staff report are those of the staff team and do not necessarily reflect the views of the Executive Board of the IMF.

- $\quad$ Supplements containing a Debt Sustainability Analysis and an Informational Annex to the staff report.

- $\quad$ A Press Release on the Executive Board Discussion

The policy of publication of staff reports and other documents allows for the deletion of market-sensitive information.

Copies of this report are available to the public from

International Monetary Fund $\bullet$ Publication Services $70019^{\text {th }}$ Street, N.W. • Washington, D.C. 20431

Telephone: (202) 623-7430 • Telefax: (202) 623-7201

E-mail: publications@imf.org Internet: http://www.imf.org

\section{International Monetary Fund Washington, D.C.}


INTERNATIONAL MONETARY FUND

ST. VINCENT AND THE GRENADINES

Request for Disbursement Under the Rapid Credit Facility

Prepared by the Western Hemisphere Department

(in Collaboration with Other Departments)

Approved by David J. Robinson and Jan Kees Martijn

February 16, 2011

\section{Executive Summary}

- Context. On October 30-31, 2010, St. Vincent and the Grenadines was hit by Hurricane Tomas, causing significant damage to agriculture, housing, and infrastructure. Preliminary and partial damage assessment done by the authorities puts the cost of damage at 5 percent of GDP. However, the costs of reconstruction and rehabilitation are expected to be much higher.

- Political Developments. Prime Minister (PM) Gonsalves was sworn in for a third term on December 15, 2010 following his party's victory in the elections on December 13, 2010. The United Labor Party, which is headed by the PM, won with a one-seat majority in the 15 -member parliament.

- Discussions and Key Recommendations. Discussions, which were done in two stages due to the elections, focused principally on the impact of the hurricane, the reconstruction and rehabilitation process, and fiscal and debt sustainability. The importance of structural reforms to improve the business climate was also discussed.

- Mission. The mission visited Kingstown during November 9-11,2010 and again during January 6-11, 2011 and met with Prime Minister and Minister of Finance Dr. Ralph Gonsalves, Director General of the Ministry of Finance Mr. Maurice Edwards, other senior government officials, as well as representatives of the financial and business sectors.

- Staff. The mission team was led by Ms. Thacker and comprised Messrs. Gonzalez-Garcia, Tashu and Acevedo (all WHD). Ms. Dawson (Caribbean Development Bank) also participated in the mission.

- Exchange Rate Regime. St. Vincent and the Grenadines is a member of the Eastern Caribbean Currency Union, which has a common central bank and currency and operates as a currency board. Since July 1976, the Eastern Caribbean dollar has been pegged to the U.S. dollar at the rate of EC\$2.7 per U.S. dollar. St. Vincent and the Grenadines has accepted the obligations of Article VIII, Sections 2, 3, and 4, and maintains an exchange system free of restrictions with respect to the making of payments and transfer for current international transactions. 


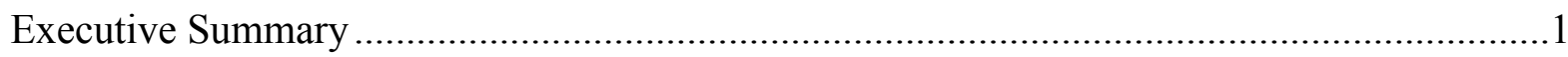

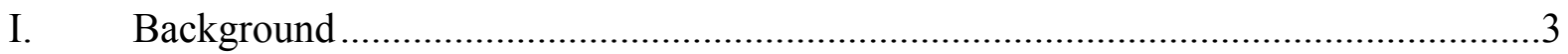

II. Economic Performance Prior to the Hurricane ..........................................................4

III. Economic Impact of the Hurricane .......................................................................6

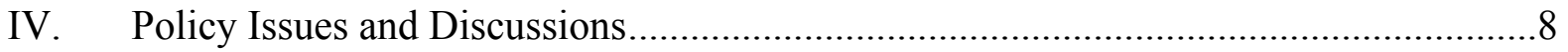

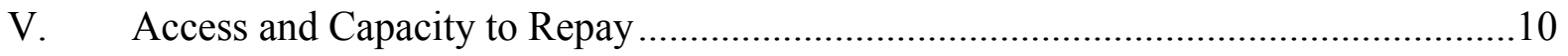

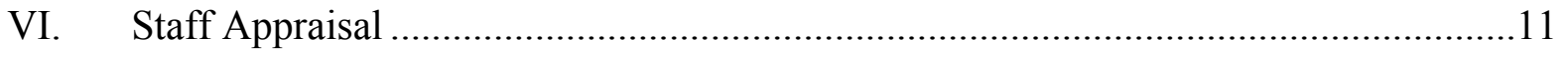

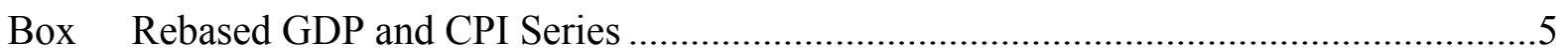

Tables

1. Selected Social and Economic Indicators, 2008-12 .............................................12

2. Summary of Central Government Operations, 2008-11 .......................................13

3. Summary of Central Government Operations, 2008-11 ...........................................14

4. Balance of Payments Summary, 2008-11 ............................................................15

5. Monetary Survey, 2008-11 ............................................................................ 16

6. Indicators of External and Financial Vulnerability, 2007-10 ................................17

7. Medium-Term Projections, 2008-16 ................................................................... 18

8. Indicators of Capacity to Repay the Fund, 2009-2021 ..........................................19

Attachment

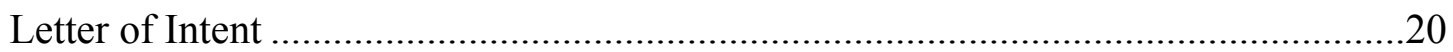




\section{BACKGROUND}

1. On October 30-31, 2010, St. Vincent and the Grenadines was hit by Hurricane Tomas; resulting in severe damage to agriculture, housing, and infrastructure.

Torrential rains combined with high winds caused severe damage to the residential housing stock, as well as to several schools and government buildings. In addition, the rains triggered landslides and flooding which caused severe damage to the island's economic infrastructure and to the agricultural sector (in particular, the banana and plantain crops were completely destroyed). The authorities' assessment, which covers the impact of the hurricane on agriculture, housing, public buildings, fisheries, livestock and forests, puts the cost of damages at 5 percent of GDP. However, reconstruction and rehabilitation, especially of the housing stock (in line with the building codes), is proving to be much more costly than the estimates from the damage assessment. Moreover, a more comprehensive assessment that includes damages to coastal areas and sea and river defenses, being conducted by the UN Economic Commission for Latin America and the Caribbean (ECLAC), is expected to raise costs further.

2. The authorities have requested a disbursement under the RCF in an amount equivalent to 25 percent of quota (SDR 2.075 million or US\$3.2 million) to address the urgent balance of payments need arising from the hurricane. ${ }^{1}$ As of end-2010, the authorities had received US\$1.1 million from the Caribbean Catastrophe Risk Insurance Fund, US\$0.2 million from the Caribbean Development Bank, and some small sums from other donors. They have also received pledges for a further US\$7.6 million in 2011, of which US\$3.6 million is expected to go through the central government, and the rest through the Housing and Land Development Corporation. ${ }^{2}$ However, rehabilitation of the banana and plantain fields, reconstruction of the destroyed housing stock and infrastructure, and rehabilitation of temporary shelters - leave a further BOP financing gap, as most materials will have to be imported. The authorities have, therefore, requested Fund assistance.

\footnotetext{
${ }^{1}$ In May 2009, St. Vincent and the Grenadines received assistance under the Exogenous Shock Facility (ESF-RAC) in amount equal to 45 percent of quota (SDR 3.74 million) to help mitigate the adverse impact of the global slowdown on the economy.

2 Donors include World Bank (US\$5.0 million in Hurricane Tomas Emergency Recovery Credit over 3 years), European Union (about US\$1.0 million in grants), Venezuela (US\$4.0 million in grants), and others.
} 
3. The authorities' stance on macroeconomic policies and record on structural reforms has generally been in line with staff recommendations. At the time of the last Article IV Consultation in May 2010, authorities agreed with staff on the need for strong fiscal consolidation over the medium term given the significant increase in public debt. However, they opted for a more back-loaded path of fiscal adjustment than recommended by staff. But with external financing falling far short of what was expected, capital spending was curtailed. As a result, the fiscal stance was tighter than what was expected at the time of the Article IV consultation (see below). On the structural front, the authorities have implemented some key measures discussed at the time of the Article IV consultation. In particular, they are adopting a

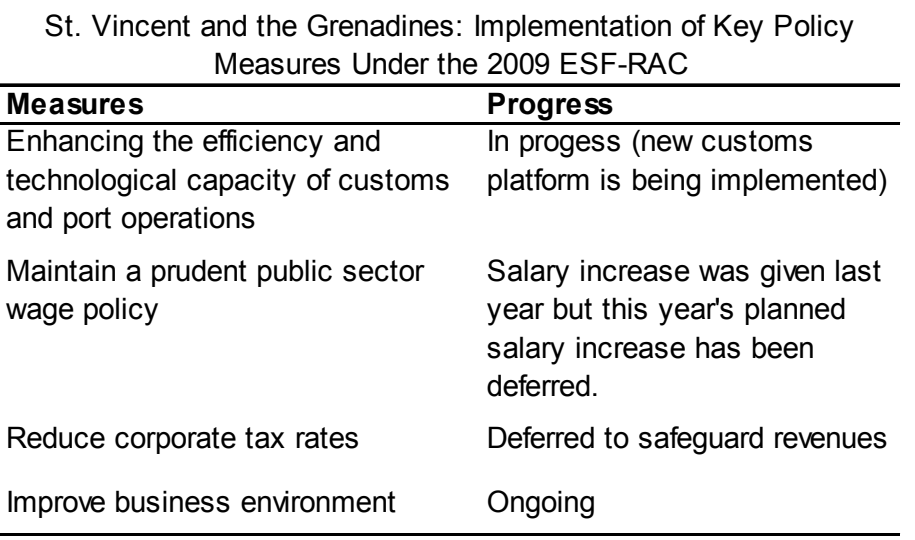
medium-term budget framework starting with the 2011 budget and implementing reforms to enhance public finance management, including operationalizing the Oversight Committee on state owned enterprises. The National Commercial Bank (NCB), which comprises about onethird of the banking sector, was privatized in November. ${ }^{3}$ They have also implemented most key measures committed to in the context of the ESF-RAC in 2009 (see Table).

\section{The authorities have officially launched the much anticipated new GDP series,} which shows an upward revision in nominal GDP by about 23 percent, on average, during 2000-09. The upward revision comes from rebasing of the National Accounts from 1990 to 2006 and from increased coverage of sectors. New sectors, such as business services, rental of machinery and equipment, computer services, private education, and private health were included in accordance with SNA (see Box for details). As the authorities are no longer using the old GDP series, references to GDP in this report reflect the new GDP, unless otherwise stated.

\section{ECONOMIC PERFORMANCE PRIOR TO THE HURRICANE}

5. Economic activity was projected to contract in 2010 , more than at the time of the last Article IV consultation. Prior to the hurricane, real GDP was projected to contract by about 2 percent in 2010, reflecting a slowdown in agriculture caused by the drought in the first half of the year, slow recovery in advanced countries (major sources of tourism and FDI), and cuts in government capital spending (see below). Average inflation was projected to increase to about 1.7 percent in 2010, from 0.4 percent in 2009 , reflecting the upward trend in international food and fuel prices since May.

\footnotetext{
${ }^{3}$ The government sold 51 percent of its stake in the NCB to Eastern Caribbean Holding Company (ECHC), with a further 29 percent to be sold in 2011; the government will retain a 20 percent share in the bank.
} 


\section{Box. Rebased GDP and CPI Series ${ }^{1}$}

The new rebased GDP increased nominal GDP by 22.9 percent on average over the 2000-2009 period. One notable change between the two series for St. Vincent and the Grenadines is that the new series shows economic growth was already declining in 2007 unlike the old series which still showed higher growth than the previous year, possibly a reflection of the change in coverage. At the same time, the overall average GDP growth is slightly higher with the new series ( 3.4 percent) than with the old one (3.3 percent), volatility is much reduced - standard deviation of growth according to the new series is 2.7 versus 3.3 according to the old series.

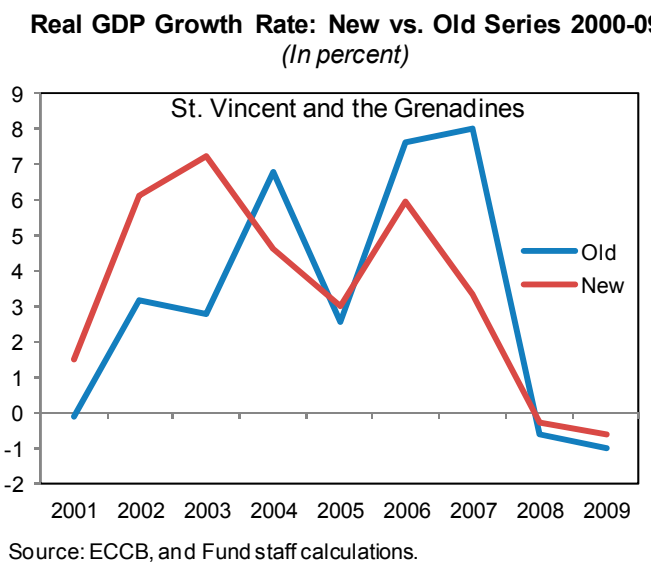

The GDP rebasing led to improvements in coverage, data sources and methodology. The revision disaggregated some industries previously classified under government into separate sectors that now include private sector activity; these are health, education and social development. The new series also improved the level of detail by estimating value added for business services, computer and related services and private households with employed persons which were not accounted for in the previous series.

The Statistical Office of St. Vincent and the Grenadines is finishing the process of updating and rebasing the CPI from base year 2001 to base year 2010. The revision process has included new data sources and adopted new international methodological and classification standards that are expected to improve the quality of the data. The new weights given to the different component of the CPI reflect a profound change in the consumption patterns of Vincentians. The share of expenditure in Housing, Fuel and Light, shows the largest increase moving from 12.8 percent in 2001 to 30.1 percent in 2010, reflecting the addition of owner's rent to the basket. Another significant change is the drop in the share of expenditure allocated to Food from 53.6 percent in 2001 to 21.9 percent in 2010. Similarly, the expenditure share for Transport and Communication rose from 6.9 percent in 2001 to 21.3 percent in 2010, reflecting in part the importance of cellular phones and mobile communication.

${ }^{1}$ A new rebased GDP series (using 2006 as the base year instead of 1990) was introduced in January 2011 with assistance from CARTAC. The Statistical Office is currently finalizing revision of the CPI weights with the assistance of CARTAC and the ECCU. These results are expected to be released during the first half of 2011. 
6. The pre-hurricane fiscal deficit was expected to be lower-than-projected, largely reflecting financing constraints. Preliminary fiscal data suggest that tax revenues were somewhat lower than projected reflecting the slowdown in the economy. On the expenditure side, significant cuts had to be made, especially on capital spending, as some of the anticipated external financing did not materialize. ${ }^{4}$ The underlying fiscal stance in 2010 was, therefore, much tighter-than-expected, with the overall fiscal deficit estimated at $5 \frac{1}{2}$ percent of GDP, compared to 11 percent of GDP projected at the time of the Article IV consultation.

7. The external current account deficit was expected to narrow in 2010. The slowdown in economic activity combined with a standstill on most FDI-related construction activities and cuts in government capital spending led to a sharp fall in imports, which along with increased transfers, more than offset the impact of the slowdown in tourism and banana exports. As a result, the current account deficit was expected to be much lower than projected.

\section{Monetary aggregates continued to reflect weak economic activity, but the} banking sector remained stable. The growth of credit to the private sector remained sluggish, growing at 2.3 percent, while broad money remained flat, in the 12 months ending October 2010. The ratio of nonperforming loans (NPLs) to total loans, declined from 8.4 percent at end-2009 to $6 \frac{1}{2}$ percent at end-September 2010 , largely reflecting the clearance of public sector NPLs at the National Commercial Bank ahead of its privatization. ${ }^{5}$ Liquidity ratios remained fairly stable and return on assets showed a marginal improvement.

\section{ECONOMIC IMPACT OF THE HURRICANE}

9. The impact of the hurricane on real GDP growth in 2010 is expected to be negative, but reconstruction activity in 2011 should help boost growth. The net impact of the hurricane on 2010 GDP growth is estimated at minus 0.3 percent, reflecting the adverse impact on agriculture, especially the banana sector and the associated

\begin{tabular}{|c|c|c|c|c|c|c|}
\hline \multicolumn{7}{|c|}{$\begin{array}{l}\text { St. Vincent and the Grenadines: Growth and Inflation, 2009-11 } \\
\text { (annual percentage change) }\end{array}$} \\
\hline & \multirow[t]{2}{*}{2009} & \multicolumn{3}{|c|}{2010} & \multicolumn{2}{|c|}{2011} \\
\hline & & Art. IV & $\begin{array}{l}\text { Rev. } \\
\text { proj. } 1 /\end{array}$ & $\begin{array}{l}\text { Post- } \\
\text { Hurricane }\end{array}$ & Art. IV & $\begin{array}{l}\text { Rev. } \\
\text { proj. }\end{array}$ \\
\hline Real GDP at factor cost & -0.6 & 0.5 & -2.0 & -2.3 & 2.0 & 2.5 \\
\hline \multicolumn{7}{|l|}{ Of which: } \\
\hline Agriculture 2/ & 6.4 & -2.5 & -6.0 & -9.7 & 2.5 & 4.0 \\
\hline Real estate and housing & 1.4 & 1.9 & 1.9 & -1.0 & 2.0 & 2.7 \\
\hline Transport 3/ & 0.1 & 0.7 & -4.3 & 0.0 & 5.0 & 3.5 \\
\hline GDP at current market prices & -0.7 & 2.0 & -0.1 & -1.0 & 4.1 & 5.0 \\
\hline Consumer prices (end of period) & -1.6 & 1.9 & 2.1 & 3.3 & 2.9 & 2.6 \\
\hline
\end{tabular}

\footnotetext{
${ }^{4}$ In particular, only US\$20 million of the total US\$50 million expected from ALBA materialized, and the supplier credit for the purchase of coastguard vessels was canceled because of financial problems with the supplier.

${ }^{5}$ The Caribbean Development Bank provided US\$37 million in Policy Based Loan, the bulk of the loan was used to clear public sector NPLs at the NCB, a precondition for its purchase by ECHC.
} 
decline in agricultural incomes ${ }^{6}$. For 2011, hurricane related reconstruction activities combined with a modest recovery in tourism and FDI-related construction will help boost growth to about $2 \frac{1}{2}$ percent, offsetting the continued adverse impact of the hurricane. ${ }^{7}$ Although the hurricane is not likely to have a significant impact on inflation in 2011, average inflation is expected to go up to about 4 percent, reflecting increasing international food and fuel prices.

10. Hurricane related spending is expected to widen the budget deficit in 2011. Last year's fiscal deficit was not much affected by hurricane related spending. The 2011 budget, announced in late January, includes additional spending of EC $\$ 16.9$ million (about 1 percent of GDP) for rehabilitation and reconstruction of the hurricane damages. This includes income support for affected farmers, field rehabilitation and fertilizer provision to affected areas, housing assistance, road improvement, and other emergency recovery projects ${ }^{8}$. Additional activities in an amount of EC $\$ 12.3$ million ( 0.6 percent of GDP) are expected to be

\begin{tabular}{lrrr}
$\begin{array}{c}\text { St Vincent and the Grenadines: Identified Financing } \\
\text { for Hurricane Related Spending } \\
\text { (In millions of EC Dollars) }\end{array}$ & & \\
& 2010 & 2011 & Total \\
\hline & $\mathbf{5 . 1}$ & $\mathbf{2 9 . 1}$ & $\mathbf{3 4 . 3}$ \\
\hline Total spending & & & \\
Of which financed by: & & & \\
Caribbean Catastrophe Risk & 3.0 & 0.0 & 3.0 \\
Insurance Fund & 0.5 & 0.0 & 0.5 \\
Caribbean Development Bank & 0.8 & 0.0 & 0.8 \\
CARICOM Development Fund & 0.0 & 2.3 & 2.3 \\
European Union & 0.3 & 0.0 & 0.3 \\
Guyana & $\mathbf{0 . 0}$ & $\mathbf{8 . 6}$ & $\mathbf{8 . 6}$ \\
IMF(RCF) & 0.5 & 0.0 & 0.5 \\
Taiwan Province of China & 0.0 & 5.4 & 5.4 \\
Suppliers credit 1/ & 0.0 & 10.8 & 10.8 \\
Venezuela & 0.0 & 2.0 & 2.0 \\
World Bank & & & \\
\hline Source: Ministry of Finance & & \\
1/ For supply of construction materials by Tank-Weld Metals of Jamaica.
\end{tabular}
executed by state-owned enterprises, mainly by the Housing and Land Development Corporation. Financing is expected to come from external grants and concessional resources.

\section{The external current account deficit is expected to widen in 2011, reflecting hurricane related imports.} Higher imports due to reconstruction and rehabilitation in the aftermath of the hurricane as well as higher international food and fuel prices will outweigh the gains from modestly improving tourism leading to a widening of the current account deficit by about 2 percentage points of GDP and a financing gap of
St Vincent and the Grenadines: Key BOP Indicators, 2009-11 (In percent of GDP, unless otherwise stated)

\begin{tabular}{|c|c|c|c|c|c|}
\hline & \multirow[t]{2}{*}{2009} & \multicolumn{2}{|c|}{2010} & \multicolumn{2}{|c|}{2011} \\
\hline & & $\begin{array}{r}\text { Art. IV } \\
\text { Proj. }\end{array}$ & $\begin{array}{r}\text { Prel. } \\
\text { est. }\end{array}$ & $\begin{array}{r}\text { Art. IV } \\
\text { Proj. }\end{array}$ & $\begin{array}{l}\text { Rev. } \\
\text { proj. }\end{array}$ \\
\hline & \multicolumn{5}{|c|}{ (In percent of the new GDP) } \\
\hline Current Accounts & -28.4 & -39.7 & -27.2 & -27.0 & -29.0 \\
\hline Exports f.o.b. & 7.7 & 7.9 & 6.9 & 8.2 & 7.3 \\
\hline Imports f.o.b. & 42.1 & 52.1 & 41.3 & 41.6 & 44.4 \\
\hline Net private transfers & 1.8 & 1.6 & 2.2 & 1.5 & 1.9 \\
\hline Foreign direct investment & 15.5 & 14.9 & 14.6 & 16.3 & 16.3 \\
\hline \multirow[t]{2}{*}{ Tourism receipts } & 12.9 & 13.3 & 11.8 & 13.5 & 11.8 \\
\hline & \multicolumn{5}{|c|}{ (In percent of the old GDP) } \\
\hline Current Accounts & -34.7 & -48.3 & -33.1 & -33.0 & -35.5 \\
\hline Exports f.o.b. & 9.4 & 9.5 & 8.4 & 10.0 & 9.0 \\
\hline Imports f.o.b. & 51.5 & 63.4 & 50.2 & 50.8 & 54.3 \\
\hline Net private transfers & 2.2 & 1.9 & 2.7 & 1.9 & 2.4 \\
\hline Foreign direct investment & 18.9 & 18.1 & 17.7 & 19.9 & 19.9 \\
\hline Tourism receipts & 15.8 & 16.1 & 14.3 & 16.5 & 14.4 \\
\hline BOP financing needs ( $E C \$$ millions) & 0.0 & 0.0 & 5.1 & 0.0 & 29.1 \\
\hline
\end{tabular}

\footnotetext{
${ }^{6}$ The impact on growth is somewhat low because: (i) the hurricane affected economic activity only in the last two months of the year, and (ii) about 35 percent of the damages were to the natural forests, which do not directly affect the national accounts.

${ }^{7}$ While agricultural production and exports will continue to decline in the first half of this year, the sector is expected to recover in the second half of the year.

${ }^{8}$ The government has also provisioned EC\$7 million and EC\$46 million, respectively, for 2012 and 2013.
} 
about $1 \frac{1}{2}$ percent of GDP. Fund financing is expected to fill about one-third of the financing gap, with the rest coming from other donors.

12. The hurricane is not expected to impact the banking sector. Commercial banks as well as credit unions have very little exposure to the agricultural sector $(0.1$ percent and 0.2 percent of total loans, respectively). On the other hand, the privatization of the NCB and the projected economic recovery are likely to have a positive impact on the overall banking sector. ${ }^{9}$

\section{Policy Issues AND Discussions}

\section{The hurricane has caused a further setback to an already ailing economy and}

posed new challenges. St Vincent and the Grenadines was already facing severe financing constraints even before it was hit by the hurricane. The hurricane has created additional demand for public resources. But with high debt levels constraining the use of fiscal policy and the currency board arrangement limiting the use of monetary policy, the authorities are depending on grants and external concessional resources to finance the reconstruction and rehabilitation expenses.

\section{The authorities' 2011 budget involves a} modest increase in the overall deficit compared to 2010, to accomodate hurricane related spending.

On the revenue side, the 2011 budget includes 0.3 percent of GDP of revenue-enhancing measures; notably, increase in license fees and stamp duties, broader coverage of properties and revaluation to current market values, and streamlining of exemptions. According to the authorities' budget, spending is slated to increase by 16 percent in 2011 , including hurricane related spending, bridge financing of the airpot project, and some expenditure items carried over from last year. ${ }^{10} 11$ Excluding the one-off items, the underlying fiscal stance is expansionary in the 2011 budget compared to the

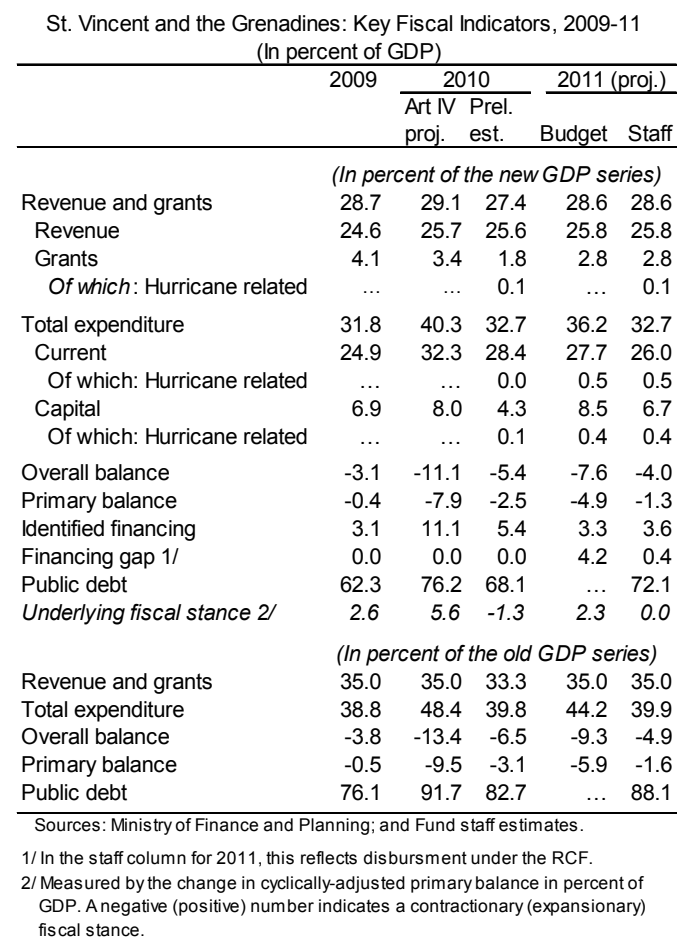

\footnotetext{
${ }^{9}$ Credit unions account for about $12 \frac{1}{2}$ percent of total banking sector assets.

${ }^{10}$ These are the cost of resolving BAICO ( $1 / 2$ percent of GDP) and purchase of coastguard vessels $(0.3$ percent of GDP). However, the magnitudes are smaller than budgeted last year.

${ }^{11}$ The authorities are using a combination of privatization proceeds, grants, and concessional resources to complete the airport project.
} 
outturn for 2010. ${ }^{12}$ However, the budget has a financing gap of about 4.2 percent of GDP, which the authorities expect to fill by expenditure savings and through additional grants and concesional financing from donors. To the extent that additional grants and concessional financing are not available, the authorities have identified contingent measures on both current and capital expenditure, notably, a limit on hiring, streamlining transfers to state-owned enterprises, and cuts in non-priority capital spending to fill the gap. In such an event, the budget will not be implemented fully, as has been the case in past years. ${ }^{13}$

\section{Staff projects the overall deficit in 2011 to be in the range of 4 percent of GDP.}

While agreeing with the authorities that the budget should accommodate hurricane related spending, staff emphasized the need to contain the wage bill, transfers and subsidies, and limit capital spending to begin the adjustment toward medium-term fiscal and debt sustainability. Moreover, given that tourism and FDI are expected to pose a modest recovery, a more neutral fiscal stance seems justifiable. While authorities agreed in principle, they emphasized the need for more infrastructure spending (there have been significant cuts in this category in the past) assuming that they are able to mobilize additional grants and/or concessional resources. However, they indicated that they do not intend to borrow on non-concessional terms and if financing fell short they would implement the contingent measures discussed above.

\section{The authorities are committed to generating primary surpluses in the range of} 11/2-2 percent of GDP over the medium term. Toward this end, the authorities plan to make further improvements in tax administration, including enhancing tax compliance, and in public finance management with CARTAC's assistance. A task force has also been set up to study the scope for pension reforms in line with CARTAC recommendations (see Letter of Intent, paragraph 5).

\section{Given the lower than projected fiscal} deficit last year, the authorities' commitment for fiscal consolidation, and the upward revision in the GDP series, the risk of external debt distress is deemed moderate. While projected to rise temporarily this year, the public sector debt-to-GDP ratio will fall over the medium term to 46 percent by 2020 (this is

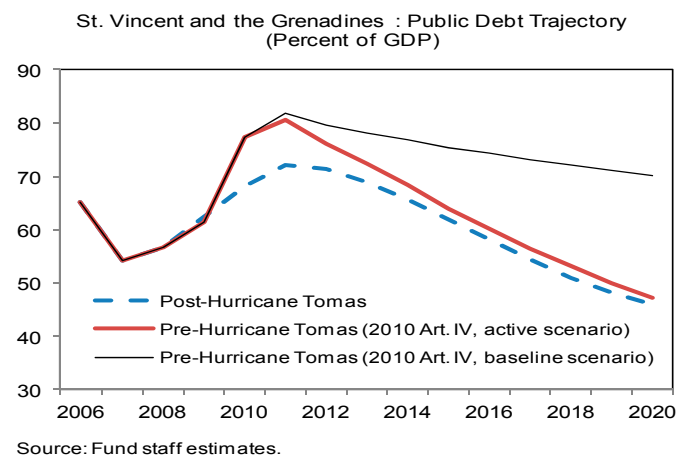

\footnotetext{
12 This is also shown in the change in the cyclically adjusted primary balance.

${ }^{13}$ Historically, the authorities tend to include a long-list of capital projects in the budget, hoping to find additional grants. However, these projects are not implemented if grants cannot be mobilized. The implementation rate of the capital budget has historically been between 40-50 percent; last year this figure was only 25 percent. As a result, the final fiscal outcome always deviates significantly from the budget, with the actual deficit far lower than in the budget.
} 
equivalent to the ECCB's target of 60 percent with the old GDP series). The Debt Sustainability Analysis also shows that the present value (PV) of external debt to GDP ratio, $\mathrm{PV}$ of external debt to exports ratio, and PV of external debt to revenue ratio, all lie below the corresponding country-specific thresholds indicating that the risk of external debt distress is moderate.

\section{The authorities have stepped up structural reforms to ensure high and sustained} growth over the medium term. To improve competitiveness, they plan to take further measures to expedite customs clearance and establish a new labor skills-building program. In order to strengthen the financial sector, the legislation for establishing the Single Regulatory Unit will be submitted to parliament in the first quarter of this year. Authorities continue to seek a regional solution to the problems left behind by the insolvency of BAICO and CLICO and intend to keep fiscal costs to a minimum, while protecting the vulnerable groups.

\section{ACCESS AND CAPACITY TO REPAY}

19. The authorities have requested a disbursement under the RCF with access of 25 percent (equivalent to SDR 2.075 million or US\$3.2 million). ${ }^{14}$ At this juncture, the authorities do not intend to request an ECF. Furthermore, given the urgent need for rapid support, there is not enough time to engage in prolonged negotiations on a Fund arrangement. While the Fund loan amounts to about 0.4 percent of GDP, it will provide some quickdisbursing funds to meet the urgent need for foreign exchange stemming from the hurricane. While other multilaterals (CDB, EU, and WB) have provided some emergency assistance and are considering further assistance, Fund financing could play a catalytic role in mobilizing these and further resources from donors.

20. It is expected that St. Vincent and the Grenadines will be able to repay its obligations to the Fund. The total outstanding loans from the Fund, once the RCF is disbursed, will amount to 70 percent of the quota. While the country remains vulnerable to exogenous shocks (economic and climate related) and the debt service-to-revenue ratio remains high at 27.8 percent (2010), the authorities' commitment to fiscal consolidation suggests that St. Vincent will have the capacity to repay the Fund as debt servicing falls due.

\section{Under the safeguards assessment policy, the Eastern Caribbean Central Bank} (ECCB) is due for an update safeguards assessment in 2011. The last assessment, completed in July 2007 (ECCB is on a four year cycle), concluded that the ECCB continues to have appropriate control mechanisms in place. Furthermore, since the assessment, the

\footnotetext{
${ }^{14}$ The proposed access level of 25 percent remains below the annual access limits ( 50 percent) in view of both debt sustainability considerations and vulnerability of St. Vincent and the Grenadines to exogenous shocks. The cumulative access, including the ESF-RAC, would stand at 70 percent of quota, still leaving some room under the cumulative limits (100 percent) of the Fund's assistance under the shocks window of the RCF.
} 
ECCB has enhanced transparency and accountability, including by publishing financial statements that comply with International Financial Reporting Standards.

\section{STAFF APPRAisAL}

22. Hurricane Tomas poses a new challenge for St Vincent and the Grenadines. The hurricane has left a trail of destruction, the severity of which stands in stark contrast to the short time span that the hurricane hit the island. While the hurricane will lead to a widening of the fiscal and current account deficits, reconstruction and rehabilitation of housing and infrastructure are expected to boost growth this year.

23. The authorities remain committed to medium term fiscal and debt sustainability, while allowing for additional hurricane related spending. The fiscal deficit in 2011 could widen somewhat, but the authorities remain committed to seeking additional grants and concessional resources to fill the remaining financial gap in the budget, while avoiding non-concessional borrowing. To the extent that these are not available the authorities plan to adjust spending, as in previous years.

24. Over the medium term the authorities remain committed to generate primary surpluses in the range of $1 \frac{1}{2}-2$ percent of GDP to ensure that the public debt-to-GDP declines. Toward this end, they plan to implement several fiscal structural measures to raise revenue and improve the efficiency of spending, as outlined in their letter accompanying this request from RCF resources. Staff also welcomes the authorities' plan to undertake pension reforms.

25. Staff supports the authorities request for the Rapid Credit Facility in the amount of SDR 2.075 million (equivalent to 25 percent of quota). Staff support is based on the severity of the damage, the urgent balance of payments need, and the authorities' policy commitment, including reliance on grants and concessional resources, and avoiding non-concessional borrowing to finance the deficit. The latter, combined with the authorities' commitment to continue fiscal structural reforms, will help to achieve medium term fiscal and debt sustainability. While there are downside risks given the country's high public debt and vulnerability to exogenous shocks, economic and natural, the authorities' commitment to fiscal consolidation mitigates these risks. 
Table 1. St. Vincent and the Grenadines: Selected Social and Economic Indicators, 2008-12

\section{Social and Demographic Indicators}

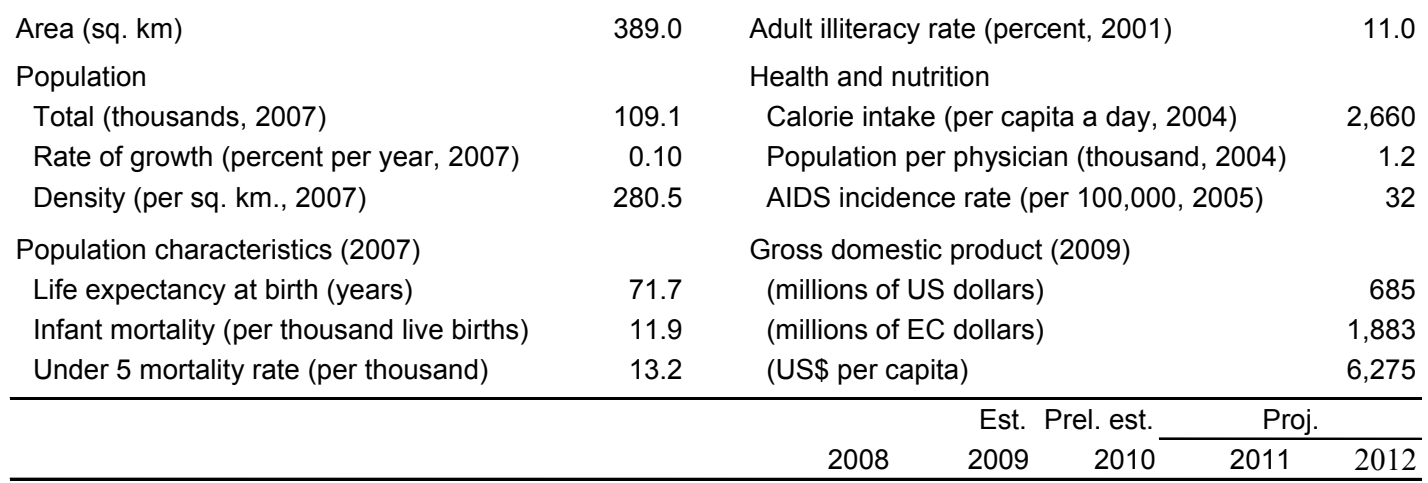

\section{Output and prices}

Real GDP (factor cost)

Nominal GDP (market prices)

Consumer prices, end of period

Consumer prices, period average

Real effective exchange rate (- = depreciation)

\section{Banking system}

Net foreign assets $1 /$

Net domestic assets 1/

Of which

Credit to private sector $1 /$

\section{Central government finances}

Total revenue and grants

Total expenditure and net lending

Current expenditure

Of which

Wages and salaries

Interest

Capital expenditure

Overall balance

Overall balance (excl. grants)

Primary balance

Primary balance (excl. grants)

Central government debt

\section{External sector}

External current account

Of which

Exports of goods and services

Imports of goods and services

Stayover arrivals (percentage change)

Public sector external debt (end of period)

External public debt service

(In percent of exports of goods and services)

\section{Memorandum items:}

Gross public sector debt

Nominal GDP (market prices; in millions of EC\$)
(Annual percentage change, unless otherwise specified)

\begin{tabular}{|c|c|c|c|c|}
\hline-0.3 & -0.6 & -2.3 & 2.5 & 2.5 \\
\hline 2.6 & -0.7 & -1.0 & 5.0 & 6.8 \\
\hline 8.7 & -1.6 & 3.3 & 2.6 & 2.5 \\
\hline 10.1 & 0.4 & 1.7 & 3.8 & 2.4 \\
\hline 3.8 & 2.4 & $\ldots$ & $\ldots$ & \\
\hline 3.1 & -2.2 & -1.8 & -2.7 & -3.1 \\
\hline-1.7 & 2.6 & 1.1 & 7.5 & 10.1 \\
\hline 2.6 & 1.5 & 1.8 & 4.9 & 6.1 \\
\hline 28.3 & 28.7 & 27.4 & 28.6 & 29.3 \\
\hline 29.6 & 31.8 & 32.7 & 32.7 & 32.3 \\
\hline 22.7 & 24.9 & 28.4 & 26.0 & 25.5 \\
\hline 10.9 & 11.3 & 11.9 & 11.6 & 11.6 \\
\hline 2.5 & 2.7 & 2.8 & 2.7 & 2.5 \\
\hline 6.9 & 6.9 & 4.3 & 6.7 & 6.8 \\
\hline-1.3 & -3.1 & -5.4 & -4.0 & -3.1 \\
\hline-3.7 & -7.2 & -7.2 & -6.8 & -5.7 \\
\hline 1.1 & -0.4 & -2.5 & -1.3 & -0.6 \\
\hline-1.3 & -4.5 & -4.4 & -4.1 & -3.2 \\
\hline 46.5 & 50.1 & 52.7 & 53.3 & 53.3 \\
\hline-28.7 & -28.4 & -27.2 & -29.0 & -27.4 \\
\hline 28.6 & 28.7 & 27.5 & 27.8 & 29.1 \\
\hline 57.3 & 57.4 & 57.2 & 58.4 & 57.6 \\
\hline-6.1 & -9.9 & -2.4 & 1.0 & 5.0 \\
\hline 30.0 & 31.8 & 40.5 & 43.4 & 42.5 \\
\hline 13.1 & 14.1 & 15.6 & 17.3 & 19.3 \\
\hline 56.7 & 62.3 & 68.1 & 72.1 & 71.4 \\
\hline 1,897 & 1,883 & 1,864 & 1,957 & 2,089 \\
\hline
\end{tabular}

Sources: ECCB; Ministry of Finance and Planning; and Fund staff estimates and projections.

1/ Annual changes relative to the stock of broad money at the beginning of the period. 
Table 2. St. Vincent and the Grenadines: Summary of Central Government Operations, 2008-11 (In millions of Eastern Caribbean dollars)

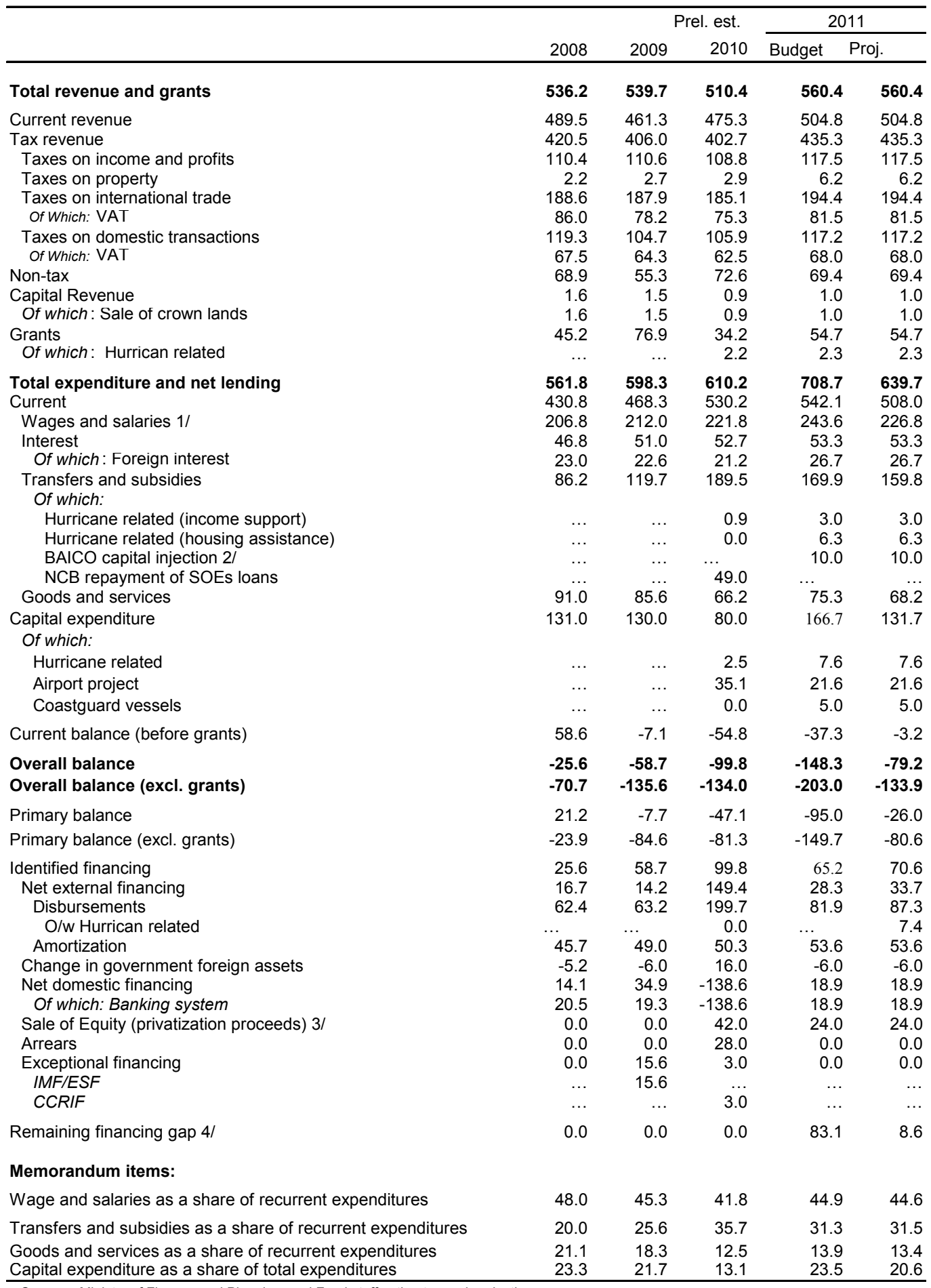

Sources: Ministry of Finance and Planning; and Fund staff estimates and projections.

$1 /$ Wages and salaries including social security contributions, commissions, rewards, allowances, and incentives.

$2 /$ In the authorities' budget, the capital injection for BAICO is classified under capital expenditure.

3/ The budget classifies privatization proceeds from the sale of the National Commercial Bank as capital revenue above the line.

4/ The financing gap in 2011 is expected to be filled by RCF. 
Table 3. St. Vincent and the Grenadines: Summary of Central Government Operations, 2008-11 (In percent of GDP, unless otherwise stated)

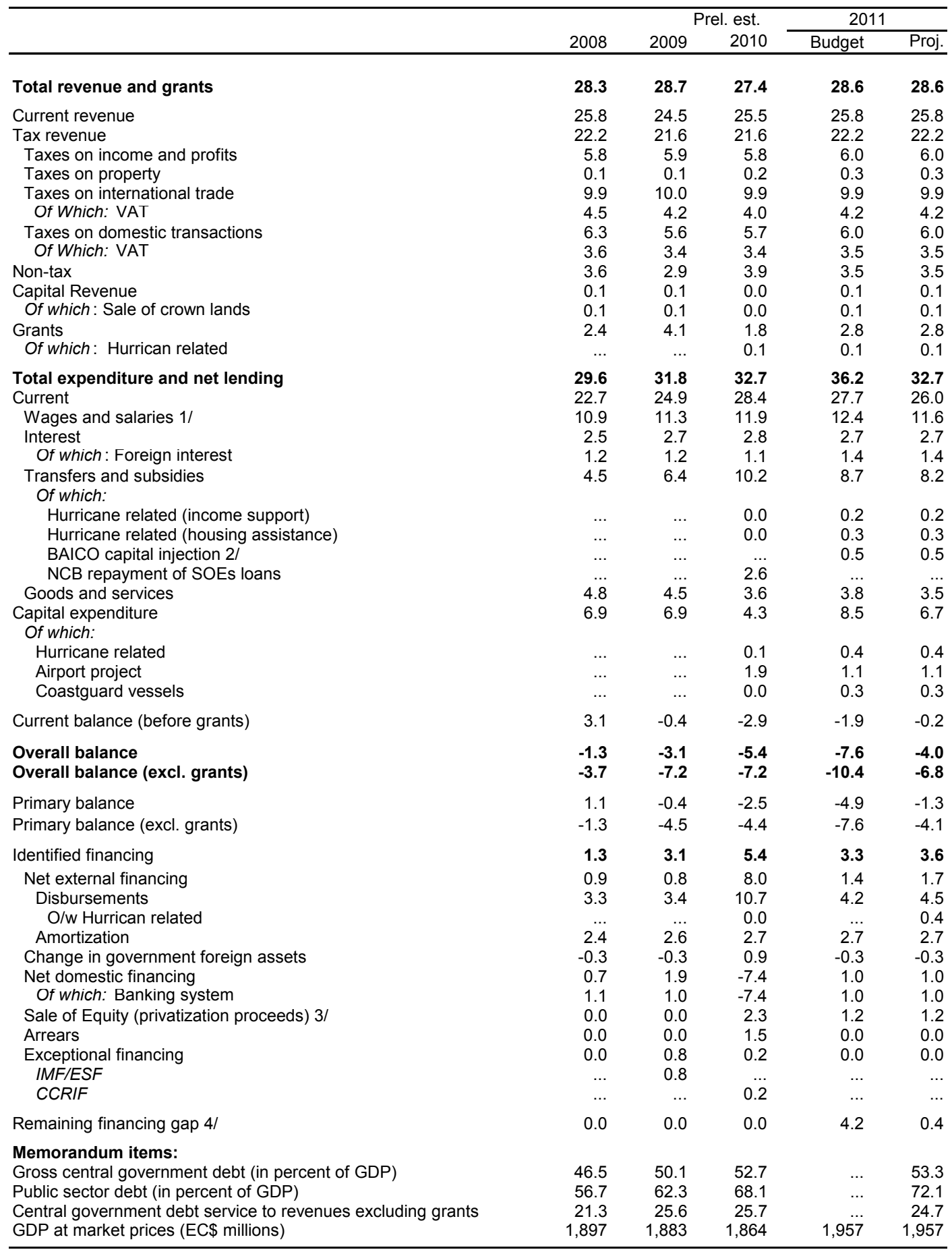

Sources: Ministry of Finance and Planning; and Fund staff estimates and projections.

$1 /$ Wages and salaries including social security contributions, commissions, rewards, allowances, and incentives. $2 /$ In the authorities' budget, the capital injection for BAICO is classified under capital expenditure.

3/ The budget classifies privatization proceeds from the sale of the National Commercial Bank as capital revenue above the line. 4/ The financing gap in 2011 is expected to be filled by RCF. 
Table 4. St. Vincent and the Grenadines: Balance of Payments Summary, 2008-11

\begin{tabular}{|c|c|c|c|c|}
\hline & \multirow[b]{2}{*}{2008} & \multirow{2}{*}{$\begin{array}{c}\text { Est. } \\
2009\end{array}$} & \multicolumn{2}{|c|}{ Rev. proj. } \\
\hline & & & 2010 & 2011 \\
\hline & \multicolumn{4}{|c|}{ (In millions of Eastern Caribbean dollars) } \\
\hline Current account & -545 & -535 & -508 & -568 \\
\hline Trade balance & -655 & -648 & -641 & -726 \\
\hline Exports f.o.b. & 151 & 146 & 129 & 144 \\
\hline Of which: Bananas & 20 & 18 & 15 & 15 \\
\hline Imports f.o.b. & 806 & 794 & 770 & 869 \\
\hline Of which: Mineral fuels & 142 & 120 & 149 & 201 \\
\hline Services (net) & 111 & 108 & 87 & 128 \\
\hline Travel & 201 & 194 & 171 & 185 \\
\hline Other nonfactor services & -90 & -86 & -84 & -58 \\
\hline Income payments (net) & -56 & -58 & -44 & -44 \\
\hline Current transfers & 55 & 63 & 89 & 73 \\
\hline Net private transfers & 33 & 33 & 42 & 38 \\
\hline Net official transfers & 22 & 30 & 47 & 35 \\
\hline Capital and financial account & 472 & 460 & 412 & 558 \\
\hline Capital & 118 & 133 & 104 & 110 \\
\hline Financial (net) & 353 & 326 & 308 & 448 \\
\hline Official capital $1 /$ & 20 & 22 & 56 & 85 \\
\hline Commercial banks & -41 & 3 & -28 & 27 \\
\hline Net Foreign Direct Investment & 327 & 292 & 271 & 319 \\
\hline Others & 48 & 10 & 9 & 16 \\
\hline Errors and omissions & 64 & 40 & 49 & 0 \\
\hline Overall balance & -9 & -36 & -47 & -10 \\
\hline Available financing & 9 & 36 & 47 & 2 \\
\hline Change in ECCB NFA & 9 & 21 & 47 & 2 \\
\hline Change in net imputed reserves (increase -) & 9 & -12 & 47 & 2 \\
\hline Of which: due to SDR allocation & 0 & -33 & 27 & 0 \\
\hline Change in medium- and long-term net liabilitie: & 0 & 33 & 0 & 0 \\
\hline Change in govt. foreign assets & 1 & 0 & 0 & 0 \\
\hline IMF purchases and disbursements & 0 & 15 & 0 & 0 \\
\hline Other financing & 0 & 0 & 0 & 0 \\
\hline Remaining financing gap 2/ & 0 & 0 & 0 & 8.6 \\
\hline
\end{tabular}

\section{Memorandum items:}

Current account

Exports f.o.b.

Imports f.o.b.

Net private transfers

Foreign direct investment

Tourism receipts

Total trade

Exports of goods and nonfactor services Imports of goods and nonfactor services
(In percent of GDP, unless otherwise stated)

$\begin{array}{rrrr}-28.7 & -28.4 & -27.2 & -29.0 \\ 8.0 & 7.7 & 6.9 & 7.3 \\ 42.5 & 42.1 & 41.3 & 44.4 \\ 1.7 & 1.8 & 2.2 & 1.9 \\ 17.2 & 15.5 & 14.6 & 16.3 \\ 13.1 & 12.9 & 11.8 & 11.8 \\ 50.5 & 49.9 & 48.3 & 51.8 \\ 28.6 & 28.7 & 27.5 & 27.8 \\ 57.3 & 57.4 & 57.2 & 58.4\end{array}$

Sources: Ministry of Finance and Planning; ECCB; and Fund staff estimates and projections. 1/ Official capital in 2010 and 2011 includes new borrowing from ALBA and CDB.

2/ All other available financing as shown in Text Table (Paragraph 10) is included as part of identified external financing. The remaining financing gap is expected to be filled by RCF. 
Table 5. St. Vincent and the Grenadines: Monetary Survey, 2008-11

\begin{tabular}{|c|c|c|c|c|}
\hline & \multirow[b]{2}{*}{2008} & \multirow[b]{2}{*}{2009} & \multicolumn{2}{|l|}{ Proi } \\
\hline & & & 2010 & 2011 \\
\hline & \multicolumn{4}{|c|}{ In millions of Eastern Caribbean dollars } \\
\hline $\begin{array}{l}\text { Net foreign assets } \\
\text { ECCB } \\
\text { Of which: Imputed reserves } \\
\text { Commercial banks }\end{array}$ & $\begin{array}{l}385 \\
224 \\
224 \\
161\end{array}$ & $\begin{array}{l}361 \\
203 \\
203 \\
158\end{array}$ & $\begin{array}{l}342 \\
156 \\
156 \\
186\end{array}$ & $\begin{array}{l}313 \\
154 \\
154 \\
158\end{array}$ \\
\hline Net domestic assets & 686 & 714 & 725 & 808 \\
\hline Public sector credit (net) & 59 & 86 & -3 & 70 \\
\hline Central government & 108 & 128 & -11 & 8 \\
\hline ECCB & 3 & -18 & 5 & 5 \\
\hline Commercial banks & 105 & 146 & -16 & 3 \\
\hline Net credit to rest of public sector & -49 & -41 & 8 & 62 \\
\hline National Insurance Scheme & -63 & -82 & -82 & -82 \\
\hline Other & 14 & 41 & 90 & 144 \\
\hline Credit to private sector & 926 & 943 & 962 & 1014 \\
\hline Other items (net) & -299 & -315 & -234 & -276 \\
\hline Broad money & 1071 & 1075 & 1067 & 1121 \\
\hline Money & 375 & 348 & 343 & 361 \\
\hline Currency in circulation & 81 & 64 & 66 & 70 \\
\hline Demand deposits & 294 & 285 & 277 & 291 \\
\hline Quasi-money & 697 & 727 & 724 & 760 \\
\hline Time deposits & 115 & 122 & 121 & 127 \\
\hline Savings deposits & 545 & 575 & 571 & 599 \\
\hline \multirow{2}{*}{ Foreign currency deposits } & 37 & 30 & 32 & 34 \\
\hline & \multicolumn{4}{|c|}{ (Annual percentage change) } \\
\hline Net foreign assets & 9.2 & -6.2 & -5.4 & -8.5 \\
\hline Net domestic assets & -2.5 & 4.0 & 1.6 & 11.5 \\
\hline Credit to private sector & 3.0 & 1.8 & 2.1 & 5.4 \\
\hline Broad money & 1.4 & 0.4 & -0.8 & 5.1 \\
\hline Money & -4.2 & -7.0 & -1.5 & 5.2 \\
\hline \multirow{2}{*}{ Quasi-money $1 /$} & 4.7 & 4.3 & -0.4 & 5.0 \\
\hline & \multicolumn{4}{|c|}{ (Contribution M2 growth) } \\
\hline Net foreign assets & 3.1 & -2.2 & -1.8 & -2.7 \\
\hline Net domestic assets & -1.7 & 2.6 & 1.1 & 7.5 \\
\hline Public sector credit (net) & 2.3 & 2.5 & -8.3 & 6.8 \\
\hline Of which: Central government & 1.9 & 1.8 & -12.9 & 1.8 \\
\hline Credit to private sector & & & & 4.9 \\
\hline Other items (net) & -6.6 & -1.5 & 7.5 & -3.9 \\
\hline \multicolumn{5}{|l|}{ Memorandum item: } \\
\hline Income velocity $2 /$ & 1.8 & 1.8 & 1.7 & 1.7 \\
\hline
\end{tabular}

Sources: ECCB; Ministry of Finance and Planning; and Fund staff estimates.

$1 /$ Including resident foreign currency deposits.

2/ Nominal GDP at market prices divided by liabilities to the private sector. 
Table 6. St. Vincent and the Grenadines: Indicators of External and Financial Vulnerability, 2007-10 (Annual percentage changes, unless otherwise specified)

\begin{tabular}{|c|c|c|c|c|}
\hline & 2007 & 2008 & 2009 & 2010 \\
\hline \multicolumn{5}{|l|}{ External indicators } \\
\hline Merchandise exports & 24.0 & 9.6 & -3.6 & $\ldots$ \\
\hline Merchandise imports & 21.1 & 3.7 & -1.6 & $\ldots$ \\
\hline Terms of trade deterioration (-) & -15.2 & 9.5 & -6.5 & $\ldots$ \\
\hline Tourism earnings & -1.9 & -17.0 & -2.4 & $\ldots$ \\
\hline Banana export earnings & 1.7 & 4.1 & -9.9 & $\ldots$ \\
\hline Current account balance (in percent of GDP) & -28.0 & -28.7 & -28.4 & $\cdots$ \\
\hline $\begin{array}{l}\text { Capital and financial account balance (in percent of GDP) 1/ } \\
\text { Of which }\end{array}$ & 35.9 & 28.2 & 26.5 & $\cdots$ \\
\hline Foreign direct investment (in percent of GDP) & 17.1 & 17.2 & 15.5 & $\ldots$ \\
\hline \multicolumn{5}{|l|}{ Gross international reserves of the ECCB } \\
\hline In millions of U.S. dollars & 764.5 & 759.0 & 800.8 & 854.3 (Nov.) \\
\hline In percent of broad money & 18.6 & 17.0 & 17.5 & 18.6 (Nov.) \\
\hline \multicolumn{5}{|l|}{ Gross imputed reserves } \\
\hline In millions of U.S. dollars & 86.2 & 82.9 & 75.2 & $\ldots$ \\
\hline Commercial banks' net foreign assets (in millions of U.S. dollars) & 44.4 & 59.7 & 58.6 & 54.4 (Nov.) \\
\hline External public debt (in percent of GDP) & 36.5 & 30.0 & 31.8 & $\ldots$ \\
\hline $\begin{array}{l}\text { External debt service (in percent of exports of goods and services) } \\
\text { Of which }\end{array}$ & 12.8 & 13.5 & 14.7 & $\cdots$ \\
\hline Interest & 4.9 & 5.8 & 5.8 & 4.1 \\
\hline Nominal exchange rate (EC\$ per US\$, end period) & 2.7 & 2.7 & 2.7 & 2.7 \\
\hline Real effective exchange rate depreciation (-), end period & 0.3 & 3.8 & 2.4 & $\cdots$ \\
\hline \multicolumn{5}{|l|}{ Financial indicators } \\
\hline Broad money & 7.2 & 1.4 & 0.4 & 1.1 (Nov.) \\
\hline Credit to the private sector & 14.1 & 3.0 & 1.8 & 3.1 (Nov.) \\
\hline \multicolumn{5}{|l|}{ Prudential indicators (in percent) } \\
\hline Regulatory capital to risk-weighted assets & 17.0 & 17.9 & 18.7 & 15.7 (Sept.) \\
\hline Nonperforming loans net of provisions to capital & 17.2 & 31.7 & 23.7 & $17.4(")$ \\
\hline Nonperforming loans to total gross loans & 3.4 & 3.9 & 8.4 & 6.4 (") \\
\hline General Government Loans to Total Loans & 21.6 & 23.1 & 17.5 & 14.5 (") \\
\hline Return on assets & 2.3 & 2.3 & 1.8 & 0.4 (") \\
\hline Liquid assets to total assets & 35.1 & 33.9 & 30.9 & 30.1 (") \\
\hline Spread between reference lending and deposit rates & 6.8 & 5.3 & 6.4 & 1.1 (") \\
\hline Total Loans/Total Deposits & 84.1 & 87.2 & 85.6 & 83.9 (") \\
\hline Foreign-currency-denominated liabilities to total liabilities & 4.5 & 5.9 & 5.1 & $4.8(")$ \\
\hline
\end{tabular}


Table 7. St. Vincent and the Grenadines: Medium-Term Projections, 2008-16 (In percent of GDP, unless otherwise specified)

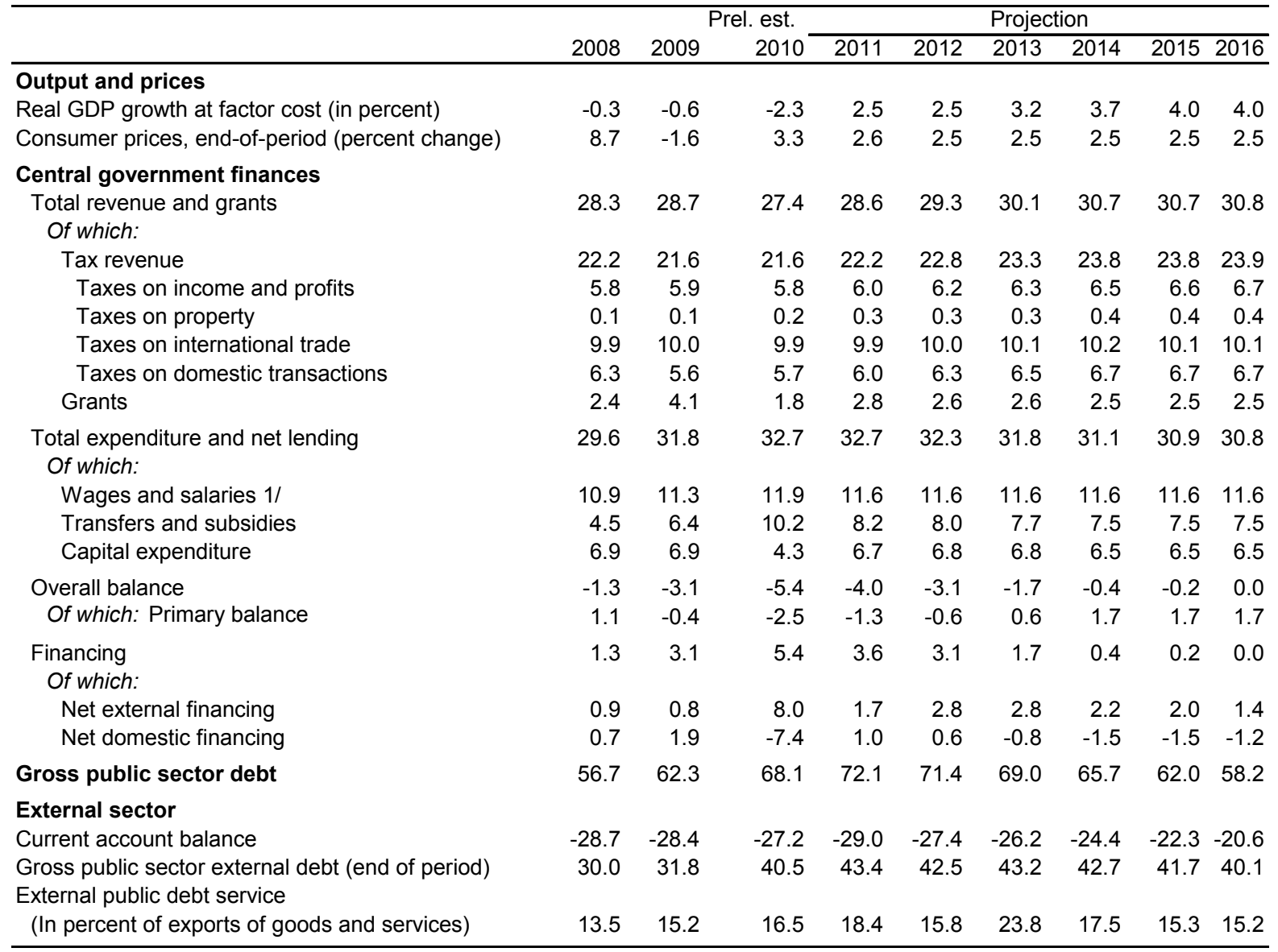

Sources: ECCB; Ministry of Finance and Planning; and Fund staff estimates and projections.

$1 /$ Wages and salaries including social security contributions, commissions, rewards, allowances, and incentives. 
Table 8. St. Vincent and the Grenadines : Indicators of Capacity to Repay the Fund, 2009-21

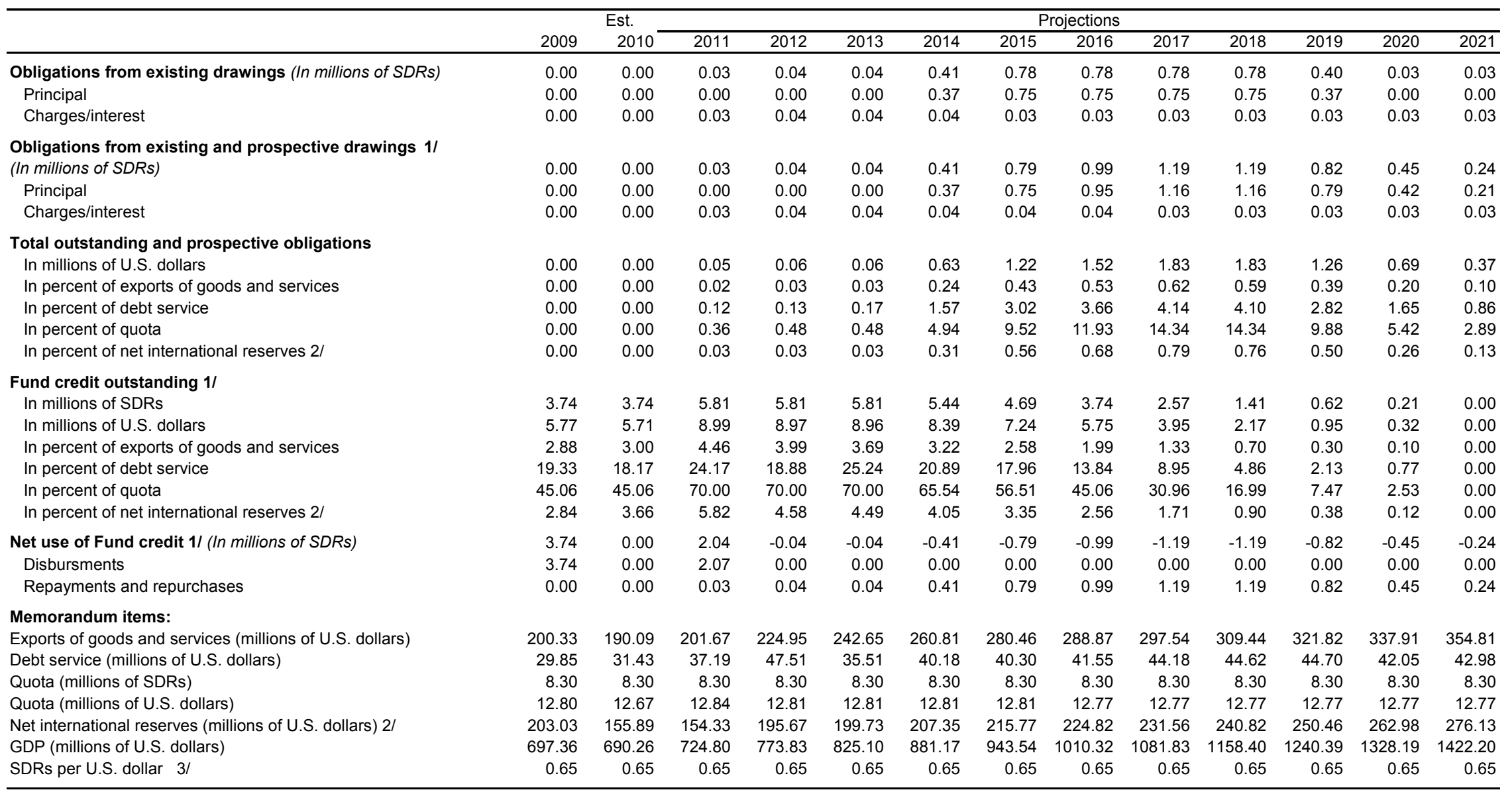

Sources: Dominica authorities; Eastern Caribbean Central Bank (ECCB); and Fund staff estimates and projections.

Assumes RCF access in the ammount of SDR 2.08 million (25 percent of quota).

2/ Net international reserves of the monetary authorities; net imputed reserves of the ECCB and transactions with the Fund.

3/ WEO GAS projections, dated December 17, 2010 up to 2016, after which the exchange rate is fixed at the 2016 level. 


\section{Attachment}

Kingstown, St Vincent and the Grenadines

February 15, 2011

Mr. Dominique Strauss-Kahn

Managing Director

International Monetary Fund

Washington, D.C. 20431

Dear Mr. Strauss-Kahn:

1. On October 30-31, 2010, St. Vincent and the Grenadines was hit by

Hurricane Tomas. Torrential rains combined with high winds caused severe damage to the residential housing stock, as well as to several schools and government buildings. In addition, the rains triggered landslides and flooding which caused severe damage to the island's economic infrastructure and to the agricultural sector (in particular the banana industry). The initial estimate of the overall damage, according to our National Emergency Management Organization, is about US\$32 million (5 percent of GDP).

2. The hurricane has setback our efforts at reactivating the economy and further exacerbated the adverse impact of the global slowdown, which has affected our tourism and construction sectors over the last three years. Real GDP growth, which was already expected to decline for a third consecutive year in 2010, is expected to have worsened further. At the same time, inflation, especially food inflation, has increased significantly adding to the negative impact, especially on the poor. While reconstruction activity is expected to boost growth in 2011, higher construction-related imports and rehabilitation of the agricultural sector will put pressure on the balance of payments.

3. On the fiscal front, the fiscal deficit will temporarily widen in 2011. However, budget execution will depend on the availability of grants and concessional resources as we will avoid borrowing on non concessional terms. If financing falls short of expectations we plan to limit new hiring, streamline transfers to state-owned enterprises and cut non-priority capital spending. The immediate post-hurricane needs were met with money received from the Caribbean Catastrophe Risk Insurance Fund, grants from donors and redirecting already allocated spending to hurricane related needs. However, we are facing significant costs from reconstruction and rehabilitation as well as to address the social needs of those affected by the hurricane. Toward this end, we are developing - with the help of donors and multilateral 
agencies - a comprehensive strategy that not only addresses the social needs but also helps to improve our resilience to such natural disasters in the future. To limit the adverse impact on our fiscal position and debt sustainability we intend to keep commercial borrowing to a minimum by limiting the financing of the rehabilitation and reconstruction effort to available grants and concessional resources. We have already received pledges and identified about EC \$21 million (out of a total of EC\$30 million required in 2011) of funding in grants and concessional loans to cover hurricane related costs.

4. Against this background, the government of St. Vincent and the Grenadines requests emergency financing from the IMF amounting to SDR million (US\$3.2 million), equivalent to 25 percent of quota under the Rapid Credit Facility. The IMF assistance will help meet the urgent foreign exchange needs stemming from the disaster, and ease pressure on our balance of payments.

5. We remain committed to fiscal consolidation and to keeping our debt trajectory on a declining path. To this end, we are targeting primary surpluses in the range of 2 percent of GDP over the medium-term through a combination of both revenue and expenditure measures. In particular, we plan to (i) improve tax compliance through enhanced enforcement and staff training, including in audits (ii) establish a Large Taxpayer Unit, (iii) broaden the coverage of property taxes, (vi) implement customs modernization through the introduction of the ASYCUDA World platform, (v) streamline exemptions, (vi) contain the wage bill, (vii) streamline spending on goods and services, and (viii) limit transfers to state owned enterprises by emphasizing efficiency and closely monitor their activities

6. On the structural front, we continue to implement key measures in line with recommendations of the Article IV consultation and CARTAC. We have adopted a medium-term budget framework starting with the 2011 budget, and we are implementing the Action Plan on public finance management and taking steps to operationalize the Oversight Committee on state owned enterprises. We have also implemented key measures we committed to in the context of our request for the ESF-RAC in 2009.

7. The government attaches great importance to implementing its agenda of structural reforms aimed at fostering macroeconomic stability and growth and reducing poverty. In this context we plan to undertake civil service and pension reforms, which could yield additional savings and improve competitiveness in the labor market. On the financial front we are working on a regional solution to the problems of BAICO and CLICO, focused on minimizing the fiscal costs to the extent possible, while ensuring equitable treatment of claimants and protecting the poor. We plan to pass the legislation for a Single Regulatory Unit in the coming period to strengthen the supervision and regulation of insurance companies, credit unions and building societies. 
8. It is hoped that the international financial community will support our efforts to restore economic growth and repair and rehabilitate our severely damaged social and economic infrastructure. We continue to seek grants and concessional resources to help meet these needs, while avoiding non-concessional borrowing. We look forward to an early approval of financial assistance by the IMF.

9. The government intends to continue to maintain a close policy dialogue with the Fund in an effort to strengthen St. Vincent's balance of payments situation, refrain from measures or policies that would compound St. Vincent's balance of payments difficulties and maintain macroeconomic stability. The government does not intend to impose new or intensify existing restrictions on the making of payments and transfers for current international transactions, introduce new or intensify existing trade restrictions for balance of payments purposes, or enter into bilateral payments agreements which are inconsistent with Article VIII of the Fund's Articles of Agreement.

Sincerely yours,

/s/

\author{
DR. THE HON. RALPH E. GONSALVES \\ PRIME MINISTER AND MINISTER OF FINANCE
}




\section{INTERNATIONAL MONETARY FUND}

\section{ST. VINCENT AND THE GRENADINES}

\section{External and Public Debt Sustainability Analysis}

Prepared by the Staff of the International Monetary Fund

February 16, 2011

The current Debt Sustainability Analysis (DSA) indicates that, under the baseline scenario discussed in the staff report, St. Vincent and the Grenadines' risk of external debt distress is moderate, compared to a high risk in the previous DSA. The public debt is also projected to resume to a sustainable trajectory over the medium term. The lower than projected fiscal deficit last year, commitment for fiscal consolidation in line with the active scenario of the previous DSA, and an upward revision in the GDP series have contributed to the improved external debt dynamics. ${ }^{l}$

\section{INTRODUCTION}

1. The 2008-09 global economic crisis has significantly affected St. Vincent and the Grenadines' economy through lowering tourism and FDI flows. Economic activity contracted by about 0.5 percent per annum, on average, during 2008-09. The impact of the external economic factors was exacerbated by Hurricane Tomas in 2010, shrinking real GDP further by 2.3 percent. Government efforts to counter these impacts have turned the primary balance from a surplus of 1.1 percent of GDP in 2008 to a deficit of $2 \frac{1}{2}$ percent of GDP in 2010. At the same time, the public sector debt-to-GDP ratio increased by 11.3 percentage points over the two year period to 68 percent in 2010 . That said, the fiscal stance in 2010 was much tighter than projected at the time of the last Article IV, reflecting external financing constraints and significant cuts in expenditure. External debt constitutes about 60 percent of the public sector debt at end-2010, of which about 60 percent represents claims by multilateral creditors. The central government owed about 90 percent of the total public sector debt at end-2010.

2. Hurricane-related reconstruction efforts will further increase the public sector debt in 2011; however, the authorities' commitment to undertake fiscal consolidation measures will ensure debt sustainability over the medium term. The authorities plan to make further improvements in tax administration, including by improving compliance and enhancing audits, and establishing a Large Taxpayer Unit. They will continue to improve

\footnotetext{
${ }^{1}$ The baseline scenario in this DSA corresponds to the "active" scenario in the previous DSA.
} 
public finance management with CARTAC assistance. A task force has also been set up to study the scope for pension reforms in line with CARTAC recommendations.

\section{UNDERLYING DSA ASSUMPTIONS}

\section{The DSA analysis is based on the following macroeconomic framework, assuming that the authorities will implement the near-term policies agreed with staff.}

- Growth and Inflation: After three consecutive years of decline, the economy is projected to rebound to $2 \frac{1}{2}$ percent in 2011 . Over the medium term, growth is projected to reach its potential level of 4 percent, equivalent to the active scenario assumption in the previous DSA. On the other hand, end-period inflation is projected to hover around 3 percent in 2010, reflecting the uptick in international food and fuel prices. Over the medium term inflation is projected to revert to its long-term path of $2-2 \frac{1}{2}$ percent.

\section{Box 1. Macroeconomic assumptions under the Baseline Scenario (2011-2030)}

- Growth is projected to rebound to around $2 \frac{1}{2}$ percent in 2011, supported by hurricane related reconstruction activities and modest recovery in tourism and FDI flows. Over the medium term, growth is assumed to return to its potential rate of 4 percent, reflecting improved employment and consumption conditions in tourism and FDI source countries. On the other hand, medium term inflation is assumed to remain low in the range of $2-2 \frac{1}{2}$ percent, anchored by the currency board arrangement.

- The primary balance of the central government is projected to improve to about $1 \frac{1}{2}-2$ percent of GDP, reflecting the authorities' commitment to fiscal consolidation. Revenue is projected to increase over the medium term, reflecting the authorities' plan to implement a number of revenue enhancing measures such as revaluation of property and broadening the coverage of the property tax, improving compliance and enhancing audits, and establishing a Large Taxpayer Unit. On the other hand, expenditure in percent of GDP is assumed to gradually fall to the pre-crisis level, reflecting the phasing out of one-off spending items. ${ }^{1 /}$

- The overall deficit is assumed to be financed increasingly from external sources, reflecting the authorities' strategy of avoiding domestic borrowing to the extent possible. However, the grant element of new external borrowing is projected to fall over the medium to long term, reflecting difficulty of accessing concessional resources as the country's income increases.

- External grants, which peaked in 2009 , is projected to return to the pre-crisis level of around $2 \frac{1}{2}$ percent of GDP over the medium term and further fall to $1 \frac{1}{2}$ percent of GDP in the long term.

- The current account deficit is projected to widen in 2011, primarily due to the increase in imports for the reconstruction, before converging to around 20 percent of GDP over the medium term. As economic conditions in source countries continue to improve, tourism and FDI inflows are assumed to rebound.

${ }^{1 /}$ These include, (i) hurricane related spending (1 percent of GDP), (ii) transfers to the airport authority (1.1 percent of GDP), (iii) provision for addressing the cost of resolving BAICO ( $1 / 2$ percent of GDP), and (iv) purchase of coastguard vessels ( 0.3 percent of GDP). The last two items are carry overs from the previous year, although the magnitudes are smaller. 
- $\quad$ Fiscal Balance: The current baseline scenario reflects the fiscal structural measures proposed under the active scenario of the previous DSA as the authorities have committed to undertake them. The 2011 budget, approved in January, already incorporates most of the proposed measures, such as broadening the property tax base, streamlining exemptions, and modernizing customs. The authorities are continuing to implement measures to improve public finance management. While the central government's primary balance is projected to register a further deficit of 1.3 percent of GDP in 2011, reflecting hurricane related and other one-off spending items, over the medium-term it is assumed that the primary surplus will be in the range of $1 \frac{1}{2}$-2percent of GDP, in line with the authorities are commitment in the context of the program discussions. $^{2}$

- External Sector: The current account deficit is projected to widen in 2011 primarily due to the increase in imports for the reconstruction, before converging to around 20 percent of GDP over the medium term. Tourism and FDI are assumed to rebound as economic recovery strengthens in source countries (mainly North America and Europe), over the medium term.

\section{Evaluation of Public Sector Debt Sustainability}

\section{Though lower than projected in the last DSA, the debt-to-GDP ratio rose by} 6 percentage points to 68 percent in 2010. The ratio is projected to increase further by another 4 percentage points to 72 percent in 2011, due to additional borrowing (concessional) for hurricane related and other one-off spending items. Fiscal consolidation measures being undertaken by the authorities are, however, expected to return the public debt to a declining path over the medium term. The public debt-to-GDP ratio is projected to fall to 46 percent of GDP by 2020 (about the same as the Eastern Caribbean Central Bank (ECCB) recommended benchmark of 60 percent with the old GDP series). ${ }^{3}$ This is comparable to the level projected under the active scenario of the previous DSA.

\section{Sensitivity analysis shows that higher primary deficit is a key vulnerability for} St. Vincent and the Grenadine's debt dynamics. Under the scenario that primary balance is unchanged at the 2010 level, which is a historically high deficit, the present value of

\footnotetext{
${ }^{2}$ The primary balance for the consolidated public sector, that is, including both the central government and the state owned enterprises, is somewhat higher in the short-term reflecting disbursements to the electricity company and the airport authority. However, the difference becomes very small after 2012.

${ }^{3}$ The authorities have officially launched the much anticipated new GDP series, which shows an upward revision in nominal GDP by about 23 percent, on average, during 2000-09.
} 
debt-to-GDP ratio will reach 87 percent in 2020 and 118 percent in 2030, compared to the base line levels of 37 percent and 20 percent in 2020 and 2030, respectively (Table 2a, Scenario A2). The scenario of permanently lower GDP growth also poses a significant risk, increasing the present value of debt-to-GDP ratio to 50 percent in 2020 and 56 percent in 2030.

\section{EVAluation OF EXTERnal DEbT Sustainability}

\section{St. Vincent and the Grenadines' risk of external debt distress is moderate,} compared to high in the previous DSA. The authorities' commitment to undertake fiscal measures proposed under the active scenario of the previous DSA, lower than projected external disbursements ${ }^{4}$ and significant expenditure cuts in 2010, and an upward revision in the GDP series have contributed to the improved external debt dynamics. That said, the PV of external debt-to-GDP ratio is projected to increase by 2 percentage points to 44 percent of GDP in 2011, reflecting the widening fiscal deficit due to hurricane related and other one-off spending items. Nevertheless, projected fiscal tightening over the medium term will reduce the ratio to 26 percent of GDP by 2020 , well below the prudential threshold of 50 percent $^{5}$ (Table 3a).

\section{Sensitivity analysis shows that St. Vincent and the Grenadines' external debt dynamics is vulnerable to changes in the nominal exchange rate and non-debt creating} flows. The stress test assuming a one-time 30 percent nominal depreciation relative to the baseline in 2011 indicates that the PV of external debt-to-GDP ratio would jump to 62 percent, breaching the country-specific threshold of 50 percent (Table 3b, Scenario B6). Similarly, the PV of external debt-to-GDP ratio would jump to 57 percent in 2011 and further to 74 percent in 2012, if the net non-debt creating flows (mainly FDI) were at the historical average minus one standard deviation in 2011-2012 (Table 3b, Scenario B4).

\footnotetext{
${ }^{4}$ For instance, the authorities only received US\$20 million of the total US\$50 million expected from ALBA, and the planned supplier credit for the purchase of coastguard vessels did not materialize due to financial problems with the supplier.

${ }^{5}$ The DSA uses policy-dependent external debt burden indicators. Policy performance is measured by the Country Policy and Institutional Assessment Index (CPIA), compiled annually by the World Bank, categorizing countries into three groups based on the quality of their macroeconomic policies (strong, medium, and poor). St. Vincent and the Grenadines is classified as a strong performer, with the thresholds on PV of debt-to-GDP, debt-to-exports, and debt-to-revenue of 50, 200 and 300 percent, respectively.

${ }^{6}$ FDI flows have been at historically low levels in the last few years due to the global economic recession.
} 


\section{ALTERNATIVE SCENARIO: ADDITIONAL BORROWING FOR THE AIRPORT PROJECT}

8. Additional borrowing in commercial terms to finance the airport project, in the rare event that all expected grants, concessional borrowing, and revenues from land sales are not available in 2011 and 2012, would put St. Vincent and the Grenadines in high risk of debt distress. Under this scenario, the public sector debt-to-GDP ratio would jump to 88 percent in 2012, compared to 71 percent in the baseline scenario, and would reach 52 percent by 2020 (above the ECCB's target of 60 percent using the old GDP series). Furthermore, all of the external debt distress indicators; the PV of external debt-to-GDP ratio, the PV of external debt to export ratio, and the PV of external debt to revenue ratio, lie above the corresponding country-specific thresholds indicating the risk of external debt distress is high.

\section{Conclusion}

9. St Vincent and the Grenadines' public debt is projected to revert to a sustainable trajectory over the medium term, achieving the ECCB's debt-to-GDP ratio target of 60 percent by 2020 . While the fiscal situation has been deteriorating in recent years, the authorities have stepped up fiscal consolidation measures, both on the revenue and expenditure fronts. These, along with projected improvements in economic prospects are expected to improve the fiscal situation and reduce the public debt-to-GDP ratio to 46 percent by 2020 .

10. St Vincent and the Grenadines' external debt risk is upgraded to moderate. Lower than projected external disbursements in 2010 the authorities' commitment to generate primary surpluses in the range of $1 \frac{1}{2}-2$ percent of GDP over the medium term, and the upward revision in GDP have contributed to the improved external debt profile. 
Figure 1. St. Vincent and the Grenadines: Indicators of Public and Publicly Guaranteed External Debt under Alternatives Scenarios, 2010-2030 1/
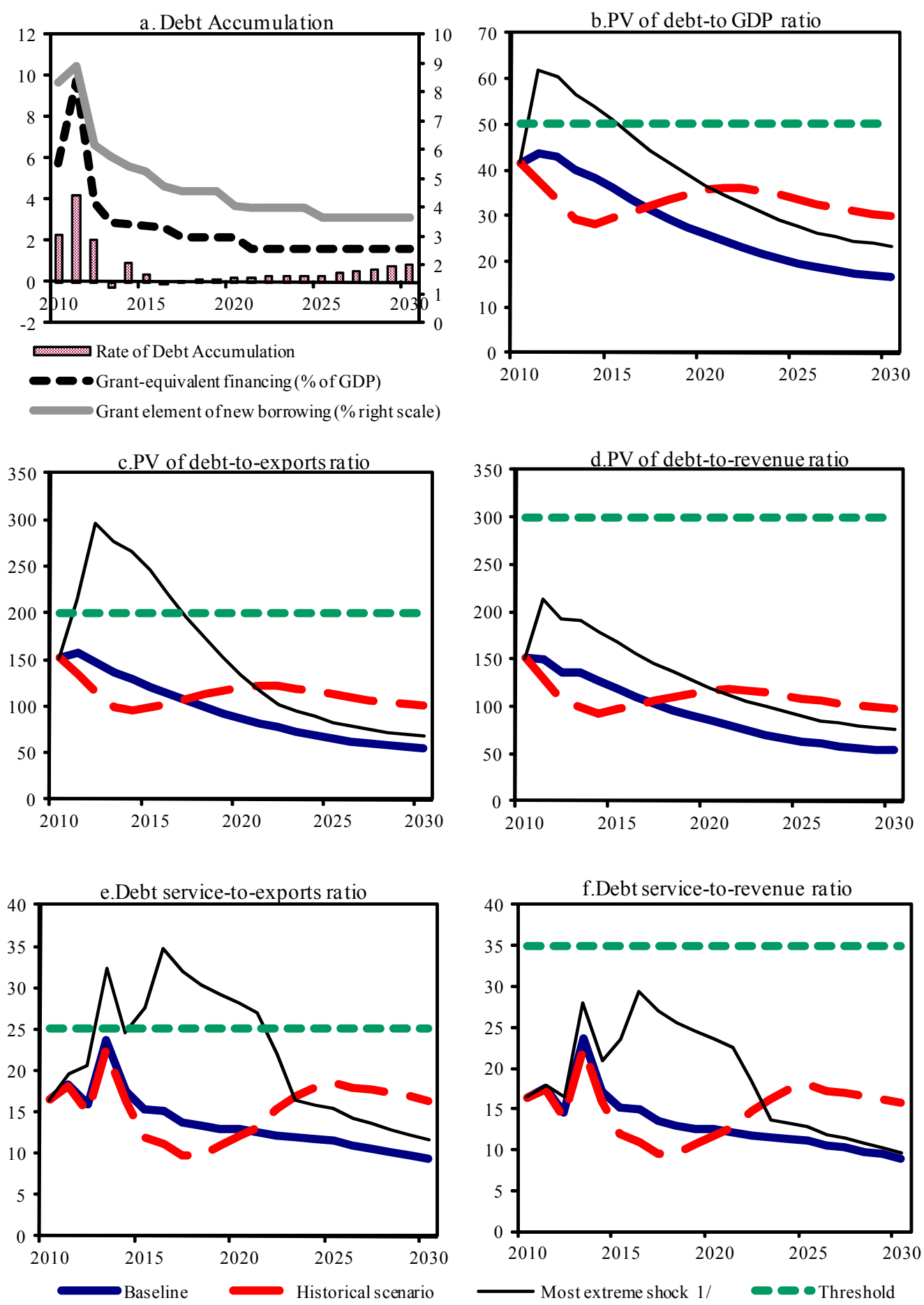

Sources: Country authorities; and staff estimates and projections.

$1 /$ The most extreme stress test is the test that yields the highest ratio in 2020. In figure $b$. it corresponds to a One-time depreciation shock; in c. to a Combination shock; in d. to a One-time depreciation shock; in e. to a Combination shock and in figure f. to a Combination shock 
Figure 2.St. Vincent and the Grenadines: Indicators of Public Debt Under Alternative Scenarios, 2010-2030 1/

- Baseline - - Fix Primary Balance - Most extreme shock One-time depreciation - Historical scenario
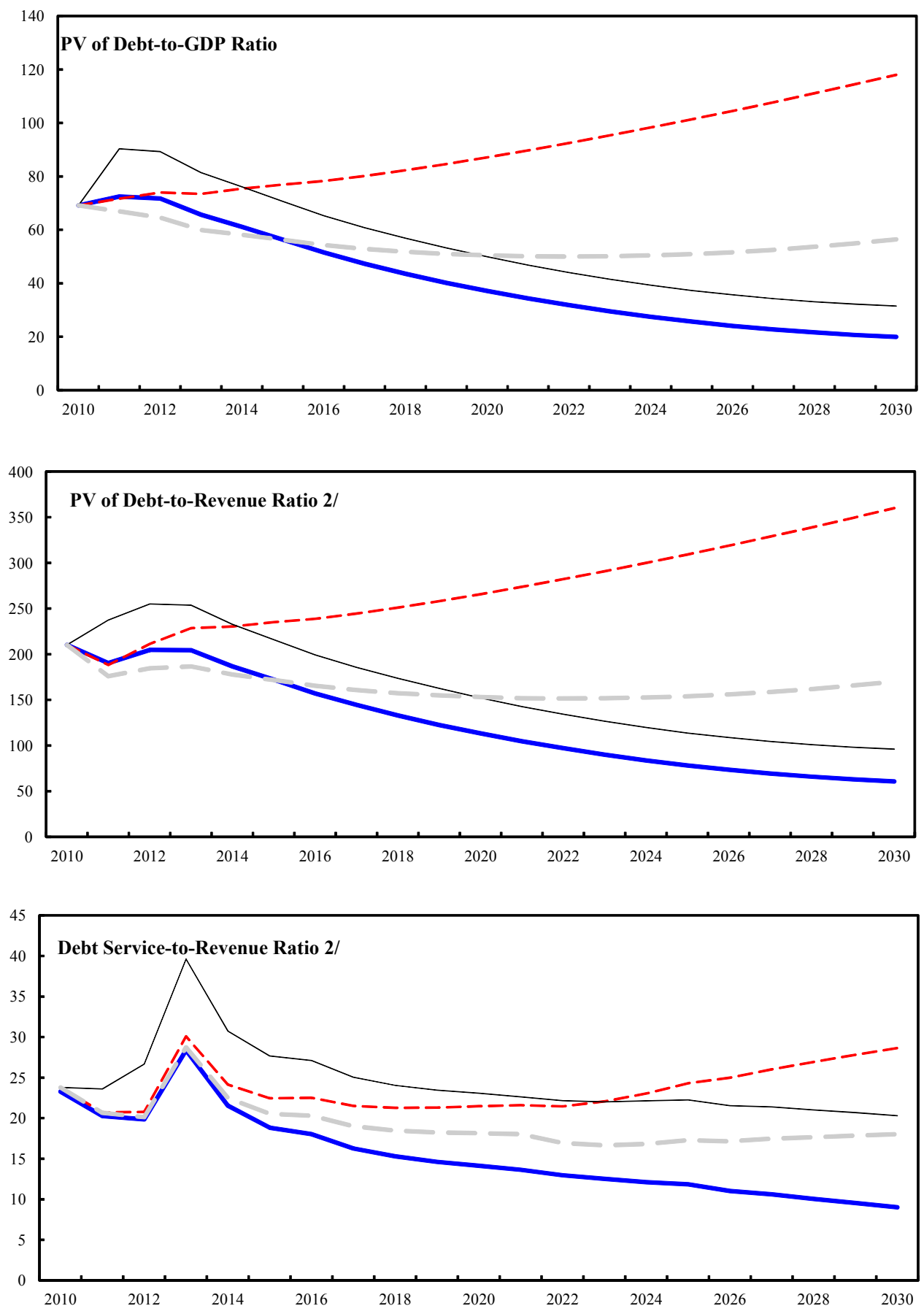

Sources: Country authorities; and staff estimates and projections.

1/ The most extreme stress test is the test that yields the highest ratio in 2020.

2/ Revenues are defined inclusive of grants. 
Figure 3. St. Vincent and the Grenadines: Indicators of Public and Publicly

Guaranteed External Debt under Borrowing for the Airport Scenario, 2010-2030
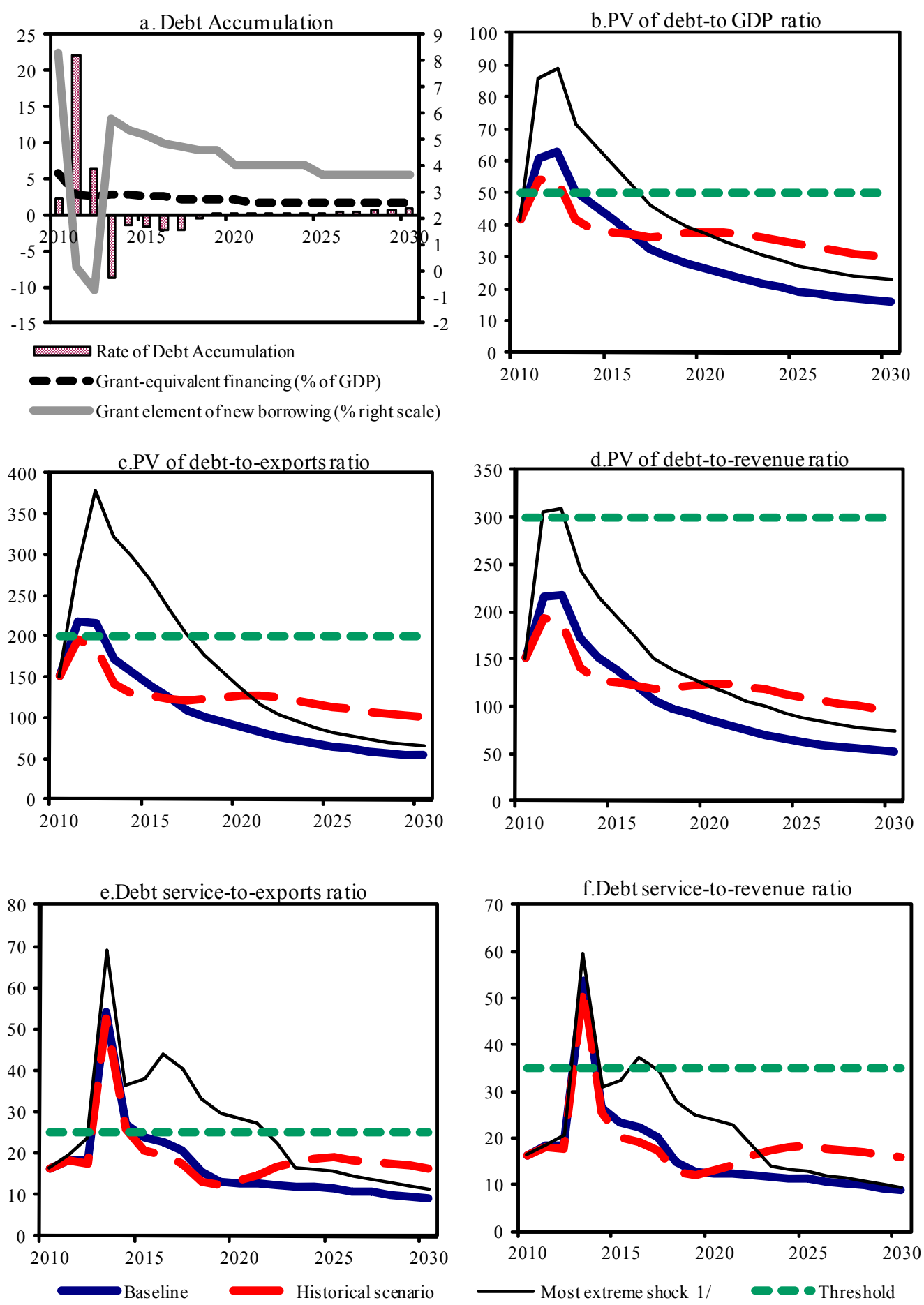

Sources: Country authorities; and staff estimates and projections.

$1 /$ The most extreme stress test is the test that yields the highest ratio in 2020. In figure $b$. it corresponds to a One-time depreciation shock; in c. to a Combination shock; in d. to a One-time depreciation shock; in e. to a Combination shock and in figure f. to a Combination shock 
Table 1a.St. Vincent and the Grenadines: Public Sector Debt Sustainability Framework, Baseline Scenario, 2007-2030 (In percent of GDP, unless otherwise indicated)

\begin{tabular}{|c|c|c|c|c|c|c|c|c|c|c|c|c|c|c|c|}
\hline & \multicolumn{3}{|c|}{ Actual } & \multirow[b]{2}{*}{ Average } & \multirow[b]{2}{*}{$\begin{array}{l}\text { Standard } \\
\text { Deviation }\end{array}$} & \multicolumn{5}{|l|}{ Estimate } & \multicolumn{5}{|c|}{ Projections } \\
\hline & 2007 & 2008 & 2009 & & & 2010 & 2011 & 2012 & 2013 & 2014 & 2015 & $\begin{array}{l}2010-15 \\
\text { Average } \\
\end{array}$ & 2020 & 2030 & $\begin{array}{l}2016-30 \\
\text { Average } \\
\end{array}$ \\
\hline $\begin{array}{l}\text { Public sector debt } 1 / \\
\text { o/w foreign-currency denominated }\end{array}$ & $\begin{array}{l}54.1 \\
29.6\end{array}$ & $\begin{array}{l}56.7 \\
30.0\end{array}$ & $\begin{array}{l}62.3 \\
31.8\end{array}$ & & & $\begin{array}{l}68.1 \\
40.5\end{array}$ & $\begin{array}{l}72.1 \\
43.4\end{array}$ & $\begin{array}{l}71.4 \\
42.5\end{array}$ & $\begin{array}{l}69.0 \\
43.2\end{array}$ & $\begin{array}{l}65.7 \\
42.7\end{array}$ & $\begin{array}{l}62.0 \\
41.7\end{array}$ & & $\begin{array}{l}46.0 \\
34.8\end{array}$ & $\begin{array}{l}35.3 \\
31.9\end{array}$ & \\
\hline Change in public sector debt & -11.2 & 2.6 & 5.6 & & & 5.7 & 4.1 & -0.7 & -2.5 & -3.3 & -3.7 & & -2.3 & -0.4 & \\
\hline Identified debt-creating flows & -0.8 & -2.1 & 5.6 & & & 6.9 & 4.8 & 0.7 & -1.9 & -3.2 & -3.3 & & -2.9 & -2.8 & \\
\hline Primary deficit & 3.4 & -3.7 & 1.8 & 0.8 & 2.4 & 5.3 & 6.1 & 2.3 & -0.2 & -1.4 & -1.4 & 1.8 & -1.4 & -1.4 & -1.4 \\
\hline Revenue and grants & 28.7 & 35.8 & 32.9 & & & 32.9 & 38.1 & 35.0 & 32.1 & 32.7 & 32.7 & & 32.8 & 32.8 & \\
\hline of which: grants & 3.2 & 5.9 & 6.7 & & & 5.3 & 9.0 & 3.5 & 2.6 & 2.5 & 2.5 & & 2.5 & 2.5 & \\
\hline Primary (noninterest) expenditure & 32.1 & 32.1 & 34.7 & & & 38.2 & 44.1 & 37.3 & 31.9 & 31.4 & 31.4 & & 31.4 & 31.4 & \\
\hline Automatic debt dynamics & -4.2 & 1.6 & 3.8 & & & 3.9 & 0.0 & -1.6 & -1.7 & -1.9 & -2.0 & & -1.5 & -1.4 & \\
\hline Contribution from interest rate/growth differential & -2.0 & 1.8 & 3.4 & & & 4.0 & 0.4 & -0.4 & -1.0 & -1.3 & -1.5 & & -1.1 & -1.1 & \\
\hline of which: contribution from average real interest rate & -0.1 & 1.7 & 3.2 & & & 2.5 & 2.1 & 1.3 & 1.3 & 1.1 & 1.0 & & 0.7 & 0.3 & \\
\hline of which: contribution from real GDP growth & -1.9 & 0.1 & 0.3 & & & 1.5 & -1.7 & -1.8 & -2.2 & -2.5 & -2.5 & & -1.9 & -1.4 & \\
\hline Contribution from real exchange rate depreciation & -2.2 & -0.2 & 0.4 & & & -0.1 & -0.5 & -1.2 & -0.7 & -0.5 & -0.5 & & & & \\
\hline Other identified debt-creating flows & 0.0 & 0.0 & 0.0 & & & -2.3 & -1.2 & 0.0 & 0.0 & 0.0 & 0.0 & & 0.0 & 0.0 & \\
\hline Privatization receipts (negative) & 0.0 & 0.0 & 0.0 & & & -2.3 & -1.2 & 0.0 & 0.0 & 0.0 & 0.0 & & 0.0 & 0.0 & \\
\hline Recognition of implicit or contingent liabilities & 0.0 & 0.0 & 0.0 & & & 0.0 & 0.0 & 0.0 & 0.0 & 0.0 & 0.0 & & 0.0 & 0.0 & \\
\hline Debt relief (HIPC and other) & 0.0 & 0.0 & 0.0 & & & 0.0 & 0.0 & 0.0 & 0.0 & 0.0 & 0.0 & & 0.0 & 0.0 & \\
\hline Other (specify, e.g. bank recapitalization) & 0.0 & 0.0 & 0.0 & & & 0.0 & 0.0 & 0.0 & 0.0 & 0.0 & 0.0 & & 0.0 & 0.0 & \\
\hline Residual, including asset changes & -10.4 & 4.7 & 0.0 & & & -1.2 & -0.7 & -1.4 & -0.5 & -0.1 & -0.3 & & 0.7 & 2.5 & \\
\hline \multicolumn{16}{|l|}{ Other Sustainability Indicators } \\
\hline PV of public sector debt & $\ldots$ & & 69.5 & & & 69.2 & 72.4 & 71.7 & 65.7 & 61.1 & 56.3 & & 37.1 & 19.9 & \\
\hline $\mathrm{o} / \mathrm{w}$ foreign-currency denominated & $\ldots$ & & 39.0 & & & 41.6 & 43.6 & 42.8 & 39.9 & 38.2 & 36.0 & & 25.9 & 16.5 & \\
\hline o/w external & $\ldots$ & $\ldots$ & 39.0 & & & 41.6 & 43.6 & 42.8 & 39.9 & 38.2 & 36.0 & & 25.9 & 16.5 & \\
\hline PV of contingent liabilities (not included in public sector debt) & & $\ldots$ & & & & & & & & & & & & & \\
\hline Gross financing need $2 /$ & 9.7 & 3.3 & 9.3 & & & 13.0 & 13.8 & 9.2 & 8.9 & 5.7 & 4.8 & & 3.2 & 1.5 & \\
\hline $\mathrm{PV}$ of public sector debt-to-revenue and grants ratio (in percent) & & & 211.2 & & & 210.3 & 190.3 & 204.8 & 204.4 & 186.8 & 172.1 & & 113.2 & 60.8 & \\
\hline PV of public sector debt-to-revenue ratio (in percent) & $\ldots$ & $\ldots$ & 265.4 & & & 250.7 & 249.4 & 227.9 & 222.5 & 202.2 & 186.4 & & 122.6 & 65.8 & \\
\hline o/w external $3 /$ & & & 148.8 & & & 150.9 & 150.3 & 135.9 & 135.1 & 126.3 & 119.0 & & 85.6 & 54.6 & \\
\hline Debt service-to-revenue and grants ratio (in percent) $4 /$ & 21.9 & 19.6 & 23.0 & & & 23.3 & 20.3 & 19.9 & 28.4 & 21.5 & 18.8 & & 14.2 & 9.0 & \\
\hline Debt service-to-revenue ratio (in percent) $4 /$ & 24.7 & 23.4 & 28.9 & & & 27.8 & 26.6 & 22.1 & 30.9 & 23.3 & 20.4 & & 15.3 & 9.8 & \\
\hline Primary deficit that stabilizes the debt-to-GDP ratio & 14.6 & -6.3 & -3.8 & & & -0.4 & 2.0 & 3.0 & 2.3 & 2.0 & 2.3 & & 0.8 & -1.1 & \\
\hline \multicolumn{16}{|l|}{ Key macroeconomic and fiscal assumptions } \\
\hline Real GDP growth (in percent) & 2.9 & -0.2 & -0.5 & 3.0 & 2.4 & -2.3 & 2.5 & 2.5 & 3.2 & 3.7 & 4.0 & 2.3 & 4.0 & 4.0 & 4.0 \\
\hline Average nominal interest rate on forex debt (in percent) & 4.0 & 4.6 & 5.1 & 4.0 & 0.8 & 4.6 & 4.6 & 4.0 & 3.8 & 3.4 & 3.3 & 3.9 & 2.7 & 1.9 & 2.4 \\
\hline Average real interest rate on domestic debt (in percent) & -2.1 & 4.1 & 7.2 & 3.9 & 3.7 & 4.3 & 3.0 & 0.8 & 1.1 & 1.7 & 2.0 & 2.2 & 3.4 & 7.6 & 4.7 \\
\hline Real exchange rate depreciation (in percent,+ indicates depreciation) & -5.5 & -0.6 & 1.2 & -1.0 & 2.9 & -0.4 & $\ldots$ & $\ldots$ & $\ldots$ & $\ldots$ & $\ldots$ & $\ldots$ & ... & $\ldots$ & $\ldots$ \\
\hline Inflation rate (GDP deflator, in percent) & 8.9 & 2.8 & -0.3 & 3.5 & 3.4 & 1.3 & 2.4 & 4.2 & 3.3 & 3.0 & 3.0 & 2.9 & 3.0 & 3.0 & 3.0 \\
\hline Growth of real primary spending (deflated by GDP deflator, in percent) & 0.1 & 0.0 & 0.1 & 0.1 & 0.1 & 0.1 & 0.2 & -0.1 & -0.1 & 0.0 & 0.0 & 0.0 & 0.0 & 0.0 & 0.0 \\
\hline Grant element of new external borrowing (in percent) & ... & $\ldots$ & ... & & & 8.3 & 8.9 & 6.1 & 5.8 & 5.4 & 5.3 & 6.6 & 4.1 & 3.6 &... \\
\hline
\end{tabular}

Sources: Country authorities; and staffe estimates and projections.

Gross finct also whether net or gross debt is used ]

3/ Revenues excluding grants.

(1)

$5 /$ Historical averages and standard deviations are generally derived over the past 10 years, subject to data availability. 
Table 2a.St. Vincent and the Grenadines: Sensitivity Analysis for Key Indicators of Public Debt 2010-2030

\begin{tabular}{|c|c|c|c|c|c|c|c|c|}
\hline & \multicolumn{8}{|c|}{ Projections } \\
\hline & 2010 & 2011 & 2012 & 2013 & 2014 & 2015 & 2020 & 2030 \\
\hline \multicolumn{9}{|c|}{ PV of Debt-to-GDP Ratio } \\
\hline Baseline & 69 & 72 & 72 & 66 & 61 & 56 & 37 & 20 \\
\hline \multicolumn{9}{|l|}{ A. Alternative scenarios } \\
\hline A1. Real GDP growth and primary balance are at historical averages & 69 & 67 & 65 & 60 & 58 & 56 & 50 & 56 \\
\hline A2. Primary balance is unchanged from 2010 & 69 & 72 & 74 & 73 & 75 & 77 & 87 & 118 \\
\hline A3. Permanently lower GDP growth $1 /$ & 69 & 73 & 73 & 68 & 64 & 60 & 48 & 53 \\
\hline A4. Alternative Scenario :[Costumize, enter title $]$ & 69 & 75 & 73 & 66 & 62 & 58 & 44 & 30 \\
\hline \multicolumn{9}{|l|}{ B. Bound tests } \\
\hline B1. Real GDP growth is at historical average minus one standard deviations in 2011-2012 & 69 & 74 & 76 & 71 & 67 & 64 & 49 & 40 \\
\hline B2. Primary balance is at historical average minus one standard deviations in 2011-2012 & 69 & 70 & 70 & 64 & 59 & 55 & 36 & 21 \\
\hline B3. Combination of B1-B2 using one half standard deviation shocks & 69 & 69 & 68 & 63 & 59 & 55 & 38 & 26 \\
\hline B4. One-time 30 percent real depreciation in 2011 & 69 & 90 & 89 & 81 & 76 & 71 & 50 & 32 \\
\hline B5. 10 percent of GDP increase in other debt-creating flows in 2011 & 69 & 82 & 81 & 75 & 70 & 65 & 45 & 28 \\
\hline \multicolumn{9}{|c|}{ PV of Debt-to-Revenue Ratio 2/ } \\
\hline Baseline & 210 & 190 & 205 & 204 & 187 & 172 & 113 & 61 \\
\hline \multicolumn{9}{|l|}{ A. Alternative scenarios } \\
\hline A1. Real GDP growth and primary balance are at historical averages & 210 & 176 & 185 & 187 & 178 & 172 & 153 & 170 \\
\hline A2. Primary balance is unchanged from 2010 & 210 & 188 & 211 & 229 & 230 & 235 & 266 & 360 \\
\hline A3. Permanently lower GDP growth $1 /$ & 210 & 191 & 208 & 210 & 195 & 183 & 145 & 160 \\
\hline A4. Alternative Scenario :[Costumize, enter title] & 210 & 425 & 313 & 272 & 255 & 241 & 185 & 124 \\
\hline \multicolumn{9}{|l|}{ B. Bound tests } \\
\hline B1. Real GDP growth is at historical average minus one standard deviations in 2011-2012 & 210 & 195 & 217 & 221 & 206 & 194 & 149 & 123 \\
\hline B2. Primary balance is at historical average minus one standard deviations in 2011-2012 & 210 & 183 & 200 & 199 & 182 & 167 & 111 & 64 \\
\hline B3. Combination of B1-B2 using one half standard deviation shocks & 210 & 181 & 195 & 196 & 180 & 167 & 116 & 78 \\
\hline B4. One-time 30 percent real depreciation in 2011 & 210 & 237 & 255 & 254 & 233 & 216 & 152 & 96 \\
\hline B5. 10 percent of GDP increase in other debt-creating flows in 2011 & 210 & 217 & 233 & 234 & 215 & 200 & 139 & 85 \\
\hline
\end{tabular}

Debt Service-to-Revenue Ratio 2/

Baseline

$\begin{array}{llllllll}23 & 20 & 20 & 28 & 22 & 19 & 14 & 9\end{array}$

\section{A. Alternative scenarios}

A1. Real GDP growth and primary balance are at historical averages

A2. Primary balance is unchanged from 2010

A3. Permanently lower GDP growth $1 /$

A4. Alternative Scenario :[Costumize, enter title]

$\begin{array}{rrrrrrrr}24 & 21 & 20 & 29 & 22 & 21 & 18 & 18 \\ 24 & 21 & 21 & 30 & 24 & 22 & 21 & 29 \\ 24 & 21 & 21 & 30 & 24 & 21 & 18 & 17 \\ 24 & 40 & 27 & 33 & 25 & 22 & 16 & 9\end{array}$

\section{B. Bound tests}

B1. Real GDP growth is at historical average minus one standard deviations in 2011-2012 B2. Primary balance is at historical average minus one standard deviations in 2011-2012

B3. Combination of B1-B2 using one half standard deviation shocks

B4. One-time 30 percent real depreciation in 2011

B5. 10 percent of GDP increase in other debt-creating flows in 2011

$\begin{array}{llllllll}24 & 21 & 22 & 31 & 24 & 22 & 18 & 15 \\ 24 & 21 & 21 & 30 & 23 & 20 & 16 & 11 \\ 24 & 21 & 21 & 30 & 23 & 21 & 16 & 12 \\ 24 & 24 & 27 & 40 & 31 & 28 & 23 & 20 \\ 24 & 21 & 22 & 31 & 24 & 22 & 17 & 13\end{array}$

Sources: Country authorities; and staff estimates and projections.

1/ Assumes that real GDP growth is at baseline minus one standard deviation divided by the square root of the length of the projection period.

2/ Revenues are defined inclusive of grants. 
Table 3a.: External Debt Sustainability Framework, Baseline Scenario, 2007-2030 1/

(In percent of GDP, unless otherwise indicated)

\begin{tabular}{|c|c|c|c|c|c|c|c|c|c|c|c|c|c|c|c|}
\hline & \multicolumn{3}{|c|}{ Actual } & \multirow{2}{*}{$\begin{aligned} \text { Historical } & 0 \\
\text { Average } & 0\end{aligned}$} & \multirow{2}{*}{$\begin{array}{l}\text { Standard } \\
\text { Deviation }\end{array}$} & \multicolumn{6}{|c|}{ Projections } & & \multirow{2}{*}{$\begin{array}{r}2016-203 \mathrm{C} \\
\text { Average }\end{array}$} \\
\hline & 2007 & 2008 & 2009 & & & 2010 & 2011 & 2012 & 2013 & 2014 & 2015 & $\begin{array}{l}\text { 2010-2013 } \\
\text { Average }\end{array}$ & 2020 & 2030 & \\
\hline External debt (nominal) 1/ & 29.6 & 30.0 & 31.8 & & & 40.5 & 43.4 & 42.5 & 43.2 & 42.7 & 41.7 & & 34.8 & 31.9 & \\
\hline o/w public and publicly guaranteed $(\mathrm{PPG})$ & 29.6 & 30.0 & 31.8 & & & 40.5 & 43.4 & 42.5 & 43.2 & 42.7 & 41.7 & & 34.8 & 31.9 & \\
\hline Change in external debt & -11.5 & 0.5 & 1.8 & & & 8.7 & 2.8 & -0.9 & 0.7 & -0.5 & -1.1 & & -0.8 & 0.1 & \\
\hline Identified net debt-creating flows & 6.5 & 10.8 & 13.2 & & & 13.4 & 11.8 & 8.9 & 7.1 & 4.8 & 2.2 & & 2.4 & 2.6 & \\
\hline Non-interest current account deficit & 26.6 & 27.4 & 26.9 & 15.7 & 10.2 & 25.8 & 27.3 & 25.7 & 24.6 & 23.1 & 21.0 & & 21.4 & 21.8 & 21.5 \\
\hline Deficit in balance of goods and services & 27.7 & 28.7 & 28.7 & & & 29.7 & 30.5 & 28.5 & 27.4 & 25.8 & 23.8 & & 23.8 & 23.8 & \\
\hline Exports & 31.1 & 28.6 & 28.7 & & & 27.5 & 27.8 & 29.1 & 29.4 & 29.6 & 29.7 & & 29.7 & 29.7 & \\
\hline Imports & 58.7 & 57.3 & 57.4 & & & 57.2 & 58.4 & 57.6 & 56.8 & 55.4 & 53.5 & & 53.5 & 53.5 & \\
\hline Net current transfers (negative $=$ inflow) & -2.9 & -2.9 & -3.4 & -2.4 & 1.3 & -4.8 & -3.7 & -3.6 & -3.8 & -4.0 & -4.1 & & -4.1 & -4.1 & -4.1 \\
\hline $\mathrm{o} / \mathrm{w}$ official & -4.7 & -4.7 & -6.1 & & & -8.3 & -6.6 & -5.5 & -5.4 & -5.3 & -5.1 & & -5.1 & -5.1 & \\
\hline Other current account flows (negative $=$ net inflow) & 1.9 & 1.6 & 1.5 & & & 0.9 & 0.5 & 0.8 & 1.0 & 1.3 & 1.3 & & 1.7 & 2.0 & \\
\hline Net FDI (negative = inflow) & -17.1 & -17.2 & -15.5 & -10.7 & 6.8 & -14.6 & -16.3 & -17.4 & -17.8 & -18.1 & -18.5 & & -18.5 & -18.5 & -18.5 \\
\hline Endogenous debt dynamics $2 /$ & -3.0 & 0.6 & 1.8 & & & 2.2 & 0.8 & 0.6 & 0.2 & -0.1 & -0.3 & & -0.4 & -0.6 & \\
\hline Contribution from nominal interest rate & 1.4 & 1.3 & 1.5 & & & 1.5 & 1.8 & 1.6 & 1.5 & 1.4 & 1.3 & & 0.9 & 0.6 & \\
\hline Contribution from real GDP growth & -1.1 & 0.1 & 0.1 & & & 0.7 & -1.0 & -1.0 & -1.3 & -1.5 & -1.6 & & -1.3 & -1.2 & \\
\hline Contribution from price and exchange rate changes & -3.4 & -0.8 & 0.1 & & & & & & & & & & & & \\
\hline $\begin{array}{l}\text { Residual (3-4) } 3 / \\
\text { o/wexceptional financing }\end{array}$ & $\begin{array}{c}-17.9 \\
0\end{array}$ & $\begin{aligned}-10.3 \\
0.0\end{aligned}$ & $\begin{array}{ll}-11.4 \\
-2.1\end{array}$ & & & $\begin{array}{r}-4.7 \\
0.0\end{array}$ & $\begin{array}{c}-8.9 \\
00\end{array}$ & $\begin{array}{cc}-9.8 \\
0.0\end{array}$ & $\begin{array}{c}-6.4 \\
0.0\end{array}$ & $\begin{aligned}-5.3 \\
0.0\end{aligned}$ & $\begin{array}{c}-3.3 \\
0.0\end{array}$ & & $\begin{aligned}-3.3 \\
0.0\end{aligned}$ & $\begin{aligned}-2.5 \\
0.0\end{aligned}$ & \\
\hline o/w exceptional financing & 0.0 & 0.0 & -2.1 & & & 0.0 & 0.0 & 0.0 & 0.0 & 0.0 & 0.0 & & 0.0 & 0.0 & \\
\hline $\begin{array}{l}\text { PV of external debt } 4 / \\
\text { In percent of exports }\end{array}$ & $\cdots$ & $\cdots$ & 39.0 & & & $\begin{array}{r}41.6 \\
1511\end{array}$ & $\begin{array}{r}43.6 \\
1568\end{array}$ & $\begin{array}{r}42.8 \\
147.1\end{array}$ & $\begin{array}{r}39.9 \\
135.6\end{array}$ & $\begin{array}{r}38.2 \\
1290\end{array}$ & $\begin{array}{r}36.0 \\
121.0\end{array}$ & & $\begin{array}{ll}25.9 \\
872\end{array}$ & 16.5 & \\
\hline $\begin{array}{l}\text { In percent of exports } \\
\text { PV of PPG external debt }\end{array}$ & ... & $\ldots .$. & 39.0 & & & $\begin{array}{r}151.1 \\
41.6\end{array}$ & $\begin{array}{r}156.8 \\
43.6\end{array}$ & $\begin{array}{r}14.1 \\
42.8\end{array}$ & $\begin{array}{r}135.0 \\
39.9\end{array}$ & 38.2 & $\begin{array}{r}32.0 \\
36.0\end{array}$ & & 25.9 & 16.5 & \\
\hline In percent of exports & ... & .... & 135.6 & & & 151.1 & 156.8 & 147.1 & 135.6 & 129.0 & 121.0 & & 87.2 & 55.6 & \\
\hline In percent of government revenues & ... & ... & 148.8 & & & 150.9 & 150.3 & 135.9 & 135.1 & 126.3 & 119.0 & & 85.6 & 54.6 & \\
\hline Debt service-to-exports ratio (in percent) & 12.8 & 13.5 & 15.2 & & & 16.5 & 18.4 & 15.8 & 23.8 & 17.5 & 15.3 & & 12.8 & 9.3 & \\
\hline PPG debt service-to-exports ratio (in percent) & 12.8 & 13.5 & 15.2 & & & 16.5 & 18.4 & 15.8 & 23.8 & 17.5 & 15.3 & & 12.8 & 9.3 & \\
\hline PPG debt service-to-revent & 15.7 & 12.9 & 16.7 & & & 16.4 & 17.6 & 14.6 & 23.7 & 17.2 & 15.1 & & 12.6 & 9.2 & \\
\hline Total gross financing need (Billions of $\mathrm{U}$ & 0.1 & 0.1 & 0.1 & & & 0.1 & 0.1 & 0.1 & 0.1 & 0.1 & 0.1 & & 0.1 & 0.2 & \\
\hline Non-interest current account deficit that stabilizes debt ratio & 38.1 & 27.0 & 25.1 & & & 17.1 & 24.4 & 26.6 & 23.9 & 23.5 & 22.1 & & 22.2 & 21.7 & \\
\hline \multicolumn{16}{|l|}{ Key macroeconomic assumptions } \\
\hline Real GDP growth (in percent) & 2.9 & -0.2 & -0.5 & 3.0 & 2.4 & -2.3 & 2.5 & 2.5 & 3.2 & 3.7 & 4.0 & 2.3 & 4.0 & 4.0 & 4.0 \\
\hline GDP deflator in US dollar terms (change in percent) & 8.9 & 2.8 & -0.3 & 3.5 & 3.4 & 1.3 & 2.4 & 4.2 & 3.3 & 3.0 & 3.0 & 2.9 & 3.0 & 3.0 & 3.0 \\
\hline Effective interest rate (percent) $5 /$ & 4.0 & 4.6 & 5.1 & 4.0 & 0.8 & 4.6 & 4.6 & 4.0 & 3.8 & 3.4 & 3.3 & 3.9 & 2.7 & 1.9 & 2.4 \\
\hline Growth of exports of G\&S (US dollar terms, in percent) & 0.3 & -5.7 & -0.2 & 1.8 & 5.4 & -5.1 & 6.1 & 11.5 & 7.9 & 7.5 & 7.5 & 5.9 & 7.1 & 7.1 & 7.1 \\
\hline Growth of imports of G\&S (US dollar terms, in percent) & 23.4 & 0.0 & -0.4 & 9.6 & 8.3 & -1.4 & 7.1 & 5.4 & 5.2 & 4.0 & 3.5 & 4.0 & 7.1 & 7.1 & 7.1 \\
\hline Grant element of new public sector borrowing (in percent) & & & & $\ldots$ & $\ldots$ & 8.3 & 8.9 & 6.1 & 5.8 & 5.4 & 5.3 & 6.6 & 4.1 & 3.6 & 4.0 \\
\hline Government revenues (excluding grants, in percent of GDP) & 25.5 & 29.9 & 26.2 & & & 27.6 & 29.0 & 31.5 & 29.5 & 30.2 & 30.2 & & 30.3 & 30.3 & 30.3 \\
\hline Aid flows (in Billions of US dollars) $7 /$ & 0.3 & 0.2 & 0.3 & & & 0.0 & 0.1 & 0.0 & 0.0 & 0.0 & 0.0 & & 0.0 & 0.1 & \\
\hline $\mathrm{o} / \mathrm{w}$ Grants & 0.0 & 0.0 & 0.0 & & & 0.0 & 0.1 & 0.0 & 0.0 & 0.0 & 0.0 & & 0.0 & 0.1 & \\
\hline $\mathrm{o} / \mathrm{w}$ Concessional loans & 0.3 & 0.2 & 0.2 & & & 0.0 & 0.0 & 0.0 & 0.0 & 0.0 & 0.0 & & 0.0 & 0.0 & \\
\hline Grant-equivalent financing (in percent of GDP) $8 /$ & $\ldots$ & $\ldots$ & $\ldots$ & & & 5.8 & 9.8 & 3.9 & 2.9 & 2.8 & 2.7 & & 2.6 & 2.6 & 2.6 \\
\hline Grant-equivalent financing (in percent of external financing) 8/ & $\ldots$ & $\ldots$ & $\ldots$ & & & 53.9 & 56.4 & 44.3 & 36.1 & 37.9 & 43.8 & & 47.0 & 46.9 & 47.1 \\
\hline \multicolumn{16}{|l|}{ Memorandum items: } \\
\hline Nominal GDP (Billions of US dollars) & 0.7 & 0.7 & 0.7 & & & 0.7 & $\begin{array}{c}0.7 \\
50\end{array}$ & 0.8 & 0.8 & 0.9 & 0.9 & & 1.3 & 2.6 & \\
\hline Nominal dollar GDP growth & 12.1 & 2.6 & -0.7 & & & -1.0 & 5.0 & 6.8 & 6.6 & 6.8 & 7.1 & 5.2 & 7.1 & 7.1 & 7.1 \\
\hline PV of PPG external debt (in Billions of US dollars) & & & 0.3 & & & 0.3 & 0.3 & 0.3 & 0.3 & 0.3 & 0.3 & & 0.3 & 0.4 & \\
\hline (PVt-PVt-1)/GDPt-1 (in percent) & & & & & & 2.2 & 4.2 & 2.0 & -0.2 & 0.9 & 0.4 & 1.6 & 0.2 & 0.9 & 0.3 \\
\hline Gross remittances (Billions of US dollars) & 0.1 & 0.1 & 0.1 & & & 0.1 & 0.1 & 0.1 & 0.1 & 0.1 & 0.1 & & 0.1 & 0.3 & \\
\hline PV of PPG external debt (in percent of GDP + remittances) & $\ldots$ & $\ldots$ & 35.8 & & & 37.8 & 39.8 & 39.0 & 36.3 & 34.7 & 32.6 & & 23.5 & 15.0 & \\
\hline PV of PPG external debt (in percent of exports + remittances) & $\ldots$ & $\ldots$ & 104.2 & & & 110.9 & 116.9 & 110.4 & 101.4 & 96.1 & 89.8 & & 64.7 & 41.3 & \\
\hline Debt service of PPG external debt (in percent of exports + remittances) & $\cdots$ & ... & 11.7 & & & 12.1 & 13.7 & 11.9 & 17.8 & 13.1 & 11.4 & & 9.5 & 6.9 & \\
\hline
\end{tabular}

Sources: Country authorities; and staff estimates and projections.

1/ Includes both public and private sector external debt.

2/ Derived as $[r-g-\rho(1+g)](1+g+\rho+g \rho)$ times previous period debt ratio, with $r=$ nominal interest rate; $g=$ real GDP growth rate, and $\rho=$ growth rate of GDP deflator in U.S. dollar terms.

3 / Includes exceptional financing (i.e., changes in arrears and debt relief); changes in gross foreign assets; and valuation adjustments. For projections also includes contribution from price and exchange rate change. 4/ Assumes that PV of private sector debt is equivalent to its face value

6/ Historical averages and standard deviations are generally derived over the past 10 years, subject to data availability.

7/ Defined as grants, concessional loans, and debt relief.

8/ Grant-equivalent financing includes grants provided directly to the government and through new borrowing (difference between the face value and the PV of new debt). 
Table 3b.St. Vincent and the Grenadines: Sensitivity Analysis for Key Indicators of Public and Publicly Guaranteed External Debt, $2010-2030$ (In percent)

\begin{tabular}{|c|c|c|c|c|c|c|c|c|}
\hline & \multicolumn{8}{|c|}{ Projections } \\
\hline & 2010 & 2011 & 2012 & 2013 & 2014 & 2015 & 2020 & 2030 \\
\hline \multicolumn{9}{|c|}{ PV of debt-to GDP ratio } \\
\hline Baseline & 42 & 44 & 43 & 40 & 38 & 36 & 26 & 17 \\
\hline \multicolumn{9}{|l|}{ A. Alternative Scenarios } \\
\hline A1. Key variables at their historical averages in 2010-2030 1/ & 42 & 37 & 34 & 29 & 28 & 29 & 36 & 30 \\
\hline A2. New public sector loans on less favorable terms in 2010-2030 2 & 42 & 45 & 45 & 42 & 41 & 39 & 30 & 23 \\
\hline \multicolumn{9}{|l|}{ B. Bound Tests } \\
\hline B1. Real GDP growth at historical average minus one standard deviation in 2011-2012 & 42 & 44 & 44 & 41 & 40 & 37 & 27 & 17 \\
\hline B2. Export value growth at historical average minus one standard deviation in 2011-2012 3/ & 42 & 46 & 51 & 48 & 46 & 43 & 28 & 17 \\
\hline B3. US dollar GDP deflator at historical average minus one standard deviation in 2011-2012 & 42 & 45 & 46 & 42 & 41 & 38 & 28 & 18 \\
\hline B4. Net non-debt creating flows at historical average minus one standard deviation in 2011-2012 4/ & 42 & 58 & 72 & 68 & 66 & 61 & 33 & 17 \\
\hline B5. Combination of B1-B4 using one-half standard deviation shocks & 42 & 57 & 74 & 71 & 68 & 63 & 34 & 17 \\
\hline B6. One-time 30 percent nominal depreciation relative to the baseline in 20115 / & 42 & 62 & 60 & 56 & 54 & 51 & 37 & 23 \\
\hline \multicolumn{9}{|c|}{ PV of debt-to-exports ratio } \\
\hline Baseline & 151 & 157 & 147 & 136 & 129 & 121 & 87 & 56 \\
\hline \multicolumn{9}{|l|}{ A. Alternative Scenarios } \\
\hline A1. Key variables at their historical averages in 2010-2030 1/ & 151 & 134 & 116 & 100 & 95 & 99 & 120 & 101 \\
\hline A2. New public sector loans on less favorable terms in 2010-2030 2 & 151 & 162 & 153 & 143 & 137 & 130 & 101 & 77 \\
\hline \multicolumn{9}{|l|}{ B. Bound Tests } \\
\hline B1. Real GDP growth at historical average minus one standard deviation in 2011-2012 & 151 & 157 & 147 & 136 & 129 & 121 & 87 & 56 \\
\hline B2. Export value growth at historical average minus one standard deviation in 2011-2012 3/ & 151 & 182 & 223 & 207 & 198 & 185 & 120 & 71 \\
\hline B3. US dollar GDP deflator at historical average minus one standard deviation in 2011-2012 & 151 & 157 & 147 & 136 & 129 & 121 & 87 & 56 \\
\hline B4. Net non-debt creating flows at historical average minus one standard deviation in 2011-2012 4/ & 151 & 208 & 248 & 233 & 223 & 206 & 111 & 56 \\
\hline B5. Combination of B1-B4 using one-half standard deviation shocks & 151 & 215 & 295 & 277 & 265 & 246 & 133 & 68 \\
\hline B6. One-time 30 percent nominal depreciation relative to the baseline in 20115 / & 151 & 157 & 147 & 136 & 129 & 121 & 87 & 56 \\
\hline
\end{tabular}

\section{PV of debt-to-revenue ratio}

Baseline

$126 \quad 119 \quad 86$

55

A. Alternative Scenarios

A1. Key variables at their historical averages in 2010-2030 1/

A2. New public sector loans on less favorable terms in 2010-2030 2

$\begin{array}{rrrrrrrr}151 & 129 & 107 & 99 & 93 & 98 & \mathbf{1 1 8} & 99 \\ 151 & 155 & 142 & 142 & 135 & 128 & \mathbf{9 9} & 76\end{array}$

\section{B. Bound Tests}

B1. Real GDP growth at historical average minus one standard deviation in 2011-2012

B2. Export value growth at historical average minus one standard deviation in 2011-2012 3/

B3. US dollar GDP deflator at historical average minus one standard deviation in 2011-2012

B4. Net non-debt creating flows at historical average minus one standard deviation in 2011-2012 4/

B5. Combination of B1-B4 using one-half standard deviation shocks

B6. One-time 30 percent nominal depreciation relative to the baseline in $20115 /$ 
Table 3b.St. Vincent and the Grenadines: Sensitivity Analysis for Key Indicators of Public and Publicly Guaranteed External Debt, $2010-2030$ (continued) (In percent)

Debt service-to-exports ratio

Baseline

A. Alternative Scenarios

A1. Key variables at their historical averages in 2010-2030 1/

A2. New public sector loans on less favorable terms in 2010-2030 2
16

16

16
18

18

18
16

24

18

15

\section{B. Bound Tests}

B1. Real GDP growth at historical average minus one standard deviation in 2011-2012

B2. Export value growth at historical average minus one standard deviation in 2011-2012 3/

B3. US dollar GDP deflator at historical average minus one standard deviation in 2011-2012

B4. Net non-debt creating flows at historical average minus one standard deviation in 2011-2012 4/

B5. Combination of B1-B4 using one-half standard deviation shocks

B6. One-time 30 percent nominal depreciation relative to the baseline in 20115 /

\section{Debt service-to-revenue ratio}

\section{Baseline}

\section{A. Alternative Scenarios}

A1. Key variables at their historical averages in 2010-2030 1/

A2. New public sector loans on less favorable terms in 2010-2030 2

\section{B. Bound Tests}

B1. Real GDP growth at historical average minus one standard deviation in 2011-2012

B2. Export value growth at historical average minus one standard deviation in 2011-2012 3/

B3. US dollar GDP deflator at historical average minus one standard deviation in 2011-2012

B4. Net non-debt creating flows at historical average minus one standard deviation in 2011-2012 4

B5. Combination of B1-B4 using one-half standard deviation shocks

B6. One-time 30 percent nominal depreciation relative to the baseline in 20115 /

Memorandum item

Grant element assumed on residual financing (i.e., financing required above baseline) 6/
16

18

$24 \quad 17$

15

13

$\begin{array}{llllllll}16 & 17 & 14 & 22 & 16 & 12 & \mathbf{1 2} & 16 \\ 16 & 18 & 15 & 14 & 12 & 12 & \mathbf{1 4} & 13\end{array}$

13

Sources: Country authorities; and staff estimates and projections.

1/ Variables include real GDP growth, growth of GDP deflator (in U.S. dollar terms), non-interest current account in percent of GDP, and non-debt creating flows.

2/ Assumes that the interest rate on new borrowing is by 2 percentage points higher than in the baseline., while grace and maturity periods are the same as in the baseline

3/ Exports values are assumed to remain permanently at the lower level, but the current account as a share of GDP is assumed to return to its baseline level after the shock (implicitly assuming an offsetting adjustment in import levels).

4/ Includes official and private transfers and FDI.

5/ Depreciation is defined as percentage decline in dollar/local currency rate, such that it never exceeds 100 percent. 


\section{INTERNATIONAL MONETARY FUND \\ ST. VINCENT AND THE GRENADINES \\ Request for Disbursement of Rapid Credit Facility \\ Informational Annex}

Prepared by the Western Hemisphere Department

February 16, 2011

Contents

Page

Appendices

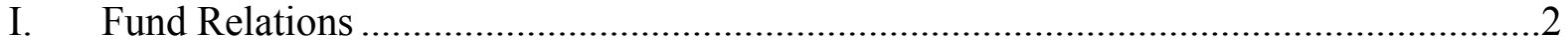

II. Relations with the World Bank Group ............................................................

III. Relations with the Caribbean Development Bank ................................................ 8

IV. European Union and St. Vincent and the Grenadines Ongoing Cooperation.................10

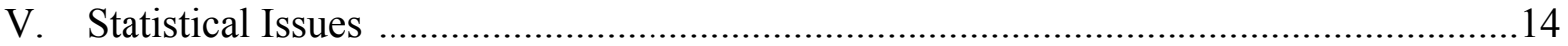


Appendix I. St. Vincent and the Grenadines: Fund Relations

(As of January 31, 2011)

I. Membership Status Joined 12/28/79; Article VIII

II. General Resources Account

Quota

Fund holdings of currency

Reserve Tranche Position

III. SDR Department

Net cumulative allocation

Holdings

IV. Outstanding Purchases and Loans:

ESF RAC Loan
SDR Million

8.30

7.80

0.50

SDR Million

7.91

0.74

SDR Million

3.74
Percent of Quota

100.00

93.98

6.02

Percent of Allocation

100.00

9.39

Percent of

Quota

45.00

V. Latest Financial Arrangements: None

VI. Projected Payments to the Fund (SDR Millions) ${ }^{1}$

\begin{tabular}{lccccr} 
& \multicolumn{3}{c}{ Forthcoming } \\
& $\mathbf{2 0 1 1}$ & $\mathbf{2 0 1 2}$ & $\mathbf{2 0 1 3}$ & $\mathbf{2 0 1 4}$ & $\mathbf{2 0 1 5}$ \\
Principal & & & & 0.37 & 0.75 \\
Charges/Interest & 0.03 & 0.04 & 0.04 & 0.04 & 0.04 \\
Total & $\mathbf{0 . 0 3}$ & $\mathbf{0 . 0 4}$ & $\mathbf{0 . 0 4}$ & $\mathbf{0 . 4 1}$ & $\mathbf{0 . 7 8}$
\end{tabular}

\footnotetext{
${ }^{1}$ Based on existing use of resources and present holdings of SDRs.
} 
VII. Exchange rate arrangement: St. Vincent and the Grenadines is a member of the Eastern Caribbean Currency Union, which has a common central bank (the Eastern Caribbean Central Bank) and currency (the Eastern Caribbean dollar). Since July 1976, the Eastern Caribbean dollar has been pegged to the U.S. dollar at the rate of EC\$2.70 per U.S. dollar. St. Vincent and the Grenadines has accepted the obligations of Article VIII, Sections 2, 3, and 4. St. Vincent and the Grenadines maintains an exchange system free of restrictions on the making of payments and transfer for current international transactions

VIII. Safeguards Assessment: Under the Fund's safeguards assessment policy, the Eastern Caribbean Central Bank (ECCB), of which St. Vincent and the Grenadines is a member, is subject to a full safeguards assessment under a four year cycle. The most recent assessment was completed in July 2007, and concluded that the ECCB continues to have appropriate control mechanisms in place, which have strengthened since the first safeguards assessment completed in 2003. ECCB management places emphasis on good governance and sound controls, and has enhanced the bank's transparency and accountability since the last assessment, including the publications of financial statements that comply with International Financial Reporting Standards. The assessment made some recommendations to sustain the ECCB's safeguards framework going forward.

IX. Article IV consultation: The last Article IV consultation was concluded by the Executive Board on July 26, 2010; the relevant document is Country Report No. 10/184. St. Vincent and the Grenadines is on a 12-month cycle.

X. Technical assistance (January 2006- ): Several missions from the Caribbean Regional Technical Assistance Centre (CARTAC), the Fiscal Affairs Department (FAD), and the Legal Department (LEG) have visited St. Vincent and the Grenadines since the beginning of 2006 to assist the authorities.

In the area of public finance, CARTAC/LEG assisted with the introduction of the VAT and excise taxes at all different stages. CARTAC also assisted to monitor the central government's fiscal performance relative to its annual targets presented in the budget. CARTAC has provided technical assistance in statistics to develop export-import prices, national accounts, and balance of payments statistics. CARTAC has also provided technical assistance in the areas of collection, enforcement, and projections of public finance and GDP. On the financial front CARTAC provided technical assistance to review and upgrade the International Insurance Act, and to develop regulations for Credit Unions. CARTAC also provided technical assistance in conducting off-site and on-site examinations on banks in international financial services industry. FAD provided technical assistance in improving tax administration, including reform and modernization of both inland revenue and customs and excise tax. FAD also provided advice on selected tax policy issues. 


\title{
Appendix II. St. Vincent and the Grenadines: Relations with the World Bank Group
}

\author{
(As of January 21, 2011)
}

The World Bank Group's Management presented to its Board the Organization of the Eastern Caribbean States (OECS) Regional Partnership Strategy (RPS) on June 8, 2010. The RPS covers the five year period July 2009-June 2014. It sets forth the terms of engagement of the International Bank for Reconstruction and Development (IBRD), the International Development Association (IDA) and the International Finance Corporation (IFC) with the countries of the Eastern Caribbean, sub-regional organizations and other development partners in pursuit of the following strategic objectives: (a) building resilience; and (b) enhancing competitiveness and stimulating growth over the medium term.

To help build resilience, the Bank Group will support interventions aimed at promoting fiscal and debt sustainability, protecting and improving human capital—particularly social safety nets, education and health — and strengthening climate resilience. To help enhance competitiveness and stimulate sustainable growth, it will focus its support on two critical areas: strengthening the countries' domestic financial sectors and improving access to quality services to create more competitive business environments. The Strategy will provide urgent remedial measures to address the crippling effects of the global and regional crises, while supporting key policy reforms that establish a platform for growth in the medium term.

The planned program of support will entail new commitments totaling up to about US\$120 million on IBRD terms and up to US\$73 million of IDA financing for the six Bank Members of the OECS, including St. Vincent and the Grenadines. St. Vincent and the Grenadines is eligible to borrow from IDA and IBRD during the period of the RPS.

\section{Projects}

There are six active World Bank projects in St. Vincent and the Grenadines for a net commitment of approximately US\$19.99 million. The Hurricane Tomas Emergency Recovery Credit Financing, which was recently approved for US\$5 million, is not yet effective.

The OECS E-Government for Regional Integration Program was approved by the Board in May 2008. The loan to St. Vincent and the Grenadines, the second in the horizontal Adaptable Program Loan series, was approved in December 2009 and consists of a US\$2.3 million IDA Credit designed to promote the efficiency, quality, and transparency of public services through the delivery of regionally integrated e-government applications that take advantage of economies of scale. The program is structured in phases. Phase 1 focuses on cross-sectoral e-government issues, as well as on specific applications in the public finance area (including Public Financial Management or PFM, tax, customs and 
procurement), and also includes an e-government in health pilot project (possibly together with preparatory and complementary activities in other social and productive sectors). Subsequent phases of the program are expected to deepen the assistance provided under Phase 1, while expanding the program to cover other sectors, in particular, education, agriculture, tourism, postal, among others, that may emerge during the early stages of implementation of Phase 1.

The OECS Catastrophe Insurance Project was approved in March 2007 for US $\$ 0.7$ million. The objective of the project is to reduce the participating OECS governments' financial vulnerability to natural disasters through insurance coverage against earthquakes and hurricanes. This will be achieved through the establishment of the Caribbean Catastrophe Risk Insurance Facility (CCRIF) and the financing of catastrophe insurance coverage from the Facility. The project will include the following two components: (a) payment of the entrance fee; and (b) payment of the annual insurance premium for the first three years. The objective of the first component is to assist the participating OECS countries to join the CCRIF through the financing of the entrance fee. This fee is equal to the first year's insurance premium. The aim of the second component is to assist the participating OECS countries to purchase the catastrophe insurance coverage offered by the CCRIF during the first three years.

The Telecommunications \& ICT Development Project, approved in May 2005 for US\$0.5 million, aims at improving the access, quality, and use of telecommunications and ICT services to achieve socio-economic development in the Organization of Eastern Caribbean States (OECS). The project has four components. Component 1 will strengthen the national and regional regulatory frameworks and promote additional competition in the telecommunications sector. Emphasis will be given on providing capacity building to the Eastern Caribbean Telecommunications Authority (ECTEL) and the National Telecommunications Regulatory Commissions (NTRCs) by assisting them in revising the regional and national sector legislation, and in developing a modem interconnection regime. Component 2 will review current universal access policy, create related guidelines, and provide financial support to establish a Universal Service Fund (USF). Component 3 will improve growth and competitiveness in ICT-enabled services through utilization of broadband infrastructure. Component 4 will finance the management and administration of the overall project. The project will finance related technical assistance by providing complementary resources.

The St. Vincent and the Grenadines Education Reform Project was approved in June 2004 for US\$6.2 million. The overall objective of this project is to build human capital which, in turn, will contribute to the diversification of the economy and more sustainable growth. This objective will be achieved by: (a) increasing equitable access to secondary education; (b) improving the quality of the teaching and learning process, with more direct 
interventions at the school level and a focus on student-centered learning; and (c) strengthening sector management and governance of schools.

The HIV/AIDS Prevention and Control Program, which was approved in July 2002, is funded under the Multi-Country APL for the Caribbean Region, with the following objectives: (a) curbing the spread of HIV/AIDS epidemic; (b) reducing the morbidity and mortality attributed to HIV/AIDS; (c) improving the quality of life for persons living with HIV/AIDS (PLWAs); and (d) developing a sustainable organizational and institutional framework for managing the HIV/AIDS epidemic over the longer term. The loan to St. Vincent and the Grenadines, one in the series of the APLs, was approved in July 2004 in the amount of US\$5.25 million.

The Hurricane Tomas Emergency Recovery Credit was approved in January 2011 for US\$5 million and aims at rehabilitating damaged infrastructure caused by the passage of Hurricane Tomas and strengthening the Government's ability to analyze location specific risks. The project has three components. Component 1 will rehabilitate and reconstruct vulnerable and damaged infrastructure. Component 2 will improve the capacity of the Ministry of Housing, Informal Human Settlements, Lands and Surveys and Physical Planning (MoHILP) and the National Emergency Management Organization (NEMO) to evaluate natural hazard and climate change risks by training their staff and providing technical advisory services and acquisition of goods. Component 3 will strengthen and develop the institutional capacity of the Public Sector Investment Program Management Unit (PSIPMU) for project management and execution, including procurement, financial management and supervision of project activities, through the acquisition of goods, provision of technical advisory services, training, and operating costs.

\section{ECONOMIC AND SECTOR WORK}

The Bank has completed a series of analytical products relating to public expenditure, fiscal and debt sustainability, growth and competitiveness, the financial sector, public sector management and social protection. The ongoing dissemination of these reports represents a key instrument for policy dialogue with the OECS governments, including St. Vincent and the Grenadines.

The Bank's program in St. Vincent and the Grenadines is further supported by a comprehensive series of completed, ongoing and planned analytical and advisory activities, including the following: "Towards a New Agenda for Growth"-OECS growth and competitiveness study (2005); An OECS Skills Enhancement Policy Note (2006); a Caribbean Air Transport Report (2006); a regional study on Crime, Violence, and Development: Trends, Costs, and Policy Options in the Caribbean (2007); an OECS Private Sector Financing Study (2008); the OECS Tourism Backward Linkages Study (2008); the report titled "Caribbean-Accelerating Trade Integration: Policy Options for Sustained 
Growth, Job Creation and Poverty Reduction" (2009); a study on the Nurse Labor \& Education Markets in the English-Speaking CARICOM: Issues and Options for Reform (2009); and a preparatory study aimed at developing a Caribbean-wide Regional Energy Strategy (ongoing).

\section{Financial Relations}

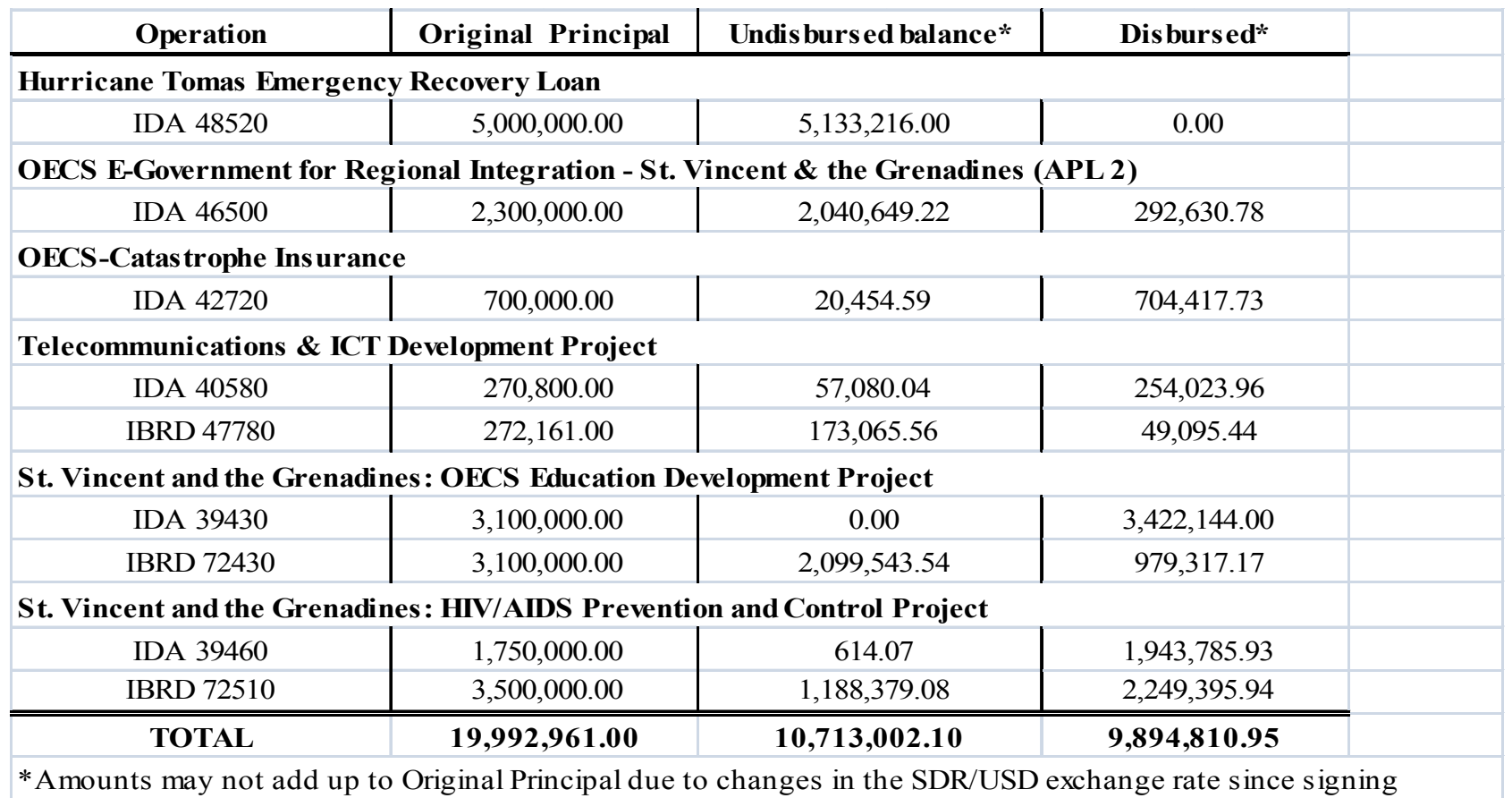

Disbursements and Debt Service (Fiscal Year Ending June 30, in millions of U.S. dollars)

\begin{tabular}{|l|r|r|r|r|r|r|r|r|r|}
\hline Period & 2003 & \multicolumn{1}{|c|}{2004} & \multicolumn{1}{|c|}{2005} & \multicolumn{1}{|c|}{2006} & 2007 & 2008 & \multicolumn{1}{c|}{2009} & 2010 & $2011^{* *}$ \\
\hline Disb Amt & 1.73 & 1.20 & 2.48 & 4.55 & 3.06 & 1.48 & 1.78 & 2.50 & 2.78 \\
\hline Repay Amt & 0.29 & 0.14 & 0.27 & 0.30 & 0.31 & 0.63 & 0.68 & 0.73 & 0.43 \\
\hline Net Amt & 1.44 & 1.06 & 2.21 & 4.25 & 2.75 & 0.85 & 1.09 & 1.77 & 2.36 \\
\hline Charges & 0.07 & 0.10 & 0.13 & 0.14 & 0.26 & 0.24 & 0.16 & 0.14 & 0.07 \\
\hline Fees & 0.05 & 0.03 & 0.06 & 0.07 & 0.04 & 0.10 & 0.16 & 0.17 & 0.08 \\
\hline
\end{tabular}




\section{Appendix III. St. Vincent and the Grenadines: Relations with the Caribbean Development Bank (CDB)}

(As of December 31, 2010)

The effects of the global financial crisis remain an ongoing challenge for the Government of St. Vincent and the Grenadines (VCT). As expenditure needs have risen, financing to support economic management, invest in infrastructure and other long-term drivers of growth, and protect those hurt by the crisis has been lacking. Assisting the government of VCT to manage these challenges has shaped CDB's interventions in VCT since 2009.

During 2010 the Bank significantly increased its funding to VCT. The Bank disbursed record lending of US\$52.7 million to assist Government to alleviate its acute financial pressures, stabilize the economy and protect core spending. Bank lending helped to ensure the continued delivery of essential public services, and finance safety net programs for the vulnerable. In the midst of increased fragility of domestic financial markets, the CDB's resources were also channeled to government to reduce vulnerabilities and strengthen the banking sector. Through policy-based lending instruments (PBL), these interventions supported key policy reforms in fiscal and tax systems, public finance management, and in the financial sector.

The largest single loan made to VCT was a PBL of US $\$ 37.0$ million to facilitate the restructuring and divestment of the state-owned bank, the National Commercial Bank. Approved by the Board of Directors in July, the loan was fully disbursed in December. The loan was used to reduce the public sector debt portfolio in the NCB and in doing so, the commercial bank's exposure to the Government. This restructuring was critical to prevent a possible collapse of the bank with adverse systemic risks for the domestic and sub-regional financial sector, and pave the way for its privatization. The NCB was sold in November. VCT also received US $\$ 12.5$ million in budget support, the second tranche of a US\$25 million macroeconomic PBL that was approved at the height of the economic crisis in 2009.

Disbursed funds in 2010 also included investment and technical assistance loans for projects under implementation in the area of education, and port rehabilitation. Bank assistance also encompassed post-disaster emergency support to respond to the ravages of Tropical Storm Tomas in October. Emergency relief grant funding of US $\$ 200,000$ dollars was provided to support, among other things, the conduct of a damage assessment, the provision of emergency relief supplies, and emergency shelter materials. VCT also received grant funding for direct poverty reduction interventions involving the development of community infrastructure under the Bank's Basic Needs Trust Fund programme, and for the development of a programme of climate change resilience.

Total cumulative loans, contingency loans, grants and equity approved for VCT amounted to US\$250 million at December 2010. Total disbursed debt outstanding to the Bank amounted to US\$148.6 million, while undisbursed loan balances stood at US\$15.2 million. 
St. Vincent and the Grenadines: Loan Disbursement (In millions of US\$)

\begin{tabular}{|l|c|c|c|c|c|c|c|c|}
\hline & $\mathbf{2 0 0 3}$ & $\mathbf{2 0 0 4}$ & $\mathbf{2 0 0 5}$ & $\mathbf{2 0 0 6}$ & $\mathbf{2 0 0 7}$ & $\mathbf{2 0 0 8}$ & $\mathbf{2 0 0 9}$ & $\mathbf{2 0 1 0}$ \\
\hline Net disbursement & 0.96 & 1.52 & 4.01 & 8.31 & 12.09 & 9.05 & 16.77 & 46.4 \\
\hline Disbursement & 3.88 & 4.61 & 7.35 & 11.35 & 15.32 & 13.02 & 21.60 & 52.7 \\
\hline Amortization & 2.92 & 3.09 & 3.34 & 3.04 & 3.23 & 3.97 & 4.83 & 6.3 \\
\hline Interest and charges & 1.92 & 1.99 & 2.11 & 2.60 & 3.22 & 3.65 & 3.53 & 3.7 \\
\hline Net resource flow & -0.96 & -0.47 & 1.9 & 5.71 & 8.87 & 5.40 & 13.24 & 42.7 \\
\hline
\end{tabular}




\section{Appendix IV. European Union and St.Vincent and the Grenadines Ongoing Cooperation}

(As of January 2011)

The total active aid portfolio for Saint Vincent and the Grenadines (VCT) stands at approximately EUR 49 million. The major ongoing projects are indicated below.

\section{Stand-Alone Projects}

\section{Tourism and Private Sector Development programme (EUR 8 million)}

The project, with several components, aims primarily to strengthen the competitiveness of the economy of VCT through interventions in Tourism. Activities include: the establishment of a Master Plan for 2007-2015; Technical Assistance for the development of a Master Plan and Tourism; Technical Assistance for a training needs assessment; the development of a tourism website; the development of the new Tourism and Hospitality Institute with a Maritime Section; the development of tourism access roads, or the construction of the walking path along the sea line in the villa area entitled: "Villa Walkway".

The allocation serves various other purposes as well, such as the strengthening of the capacity of the statistics department of VCT, including the establishment of Tourism Satellite Accounts, development of a statistical website, capacity building, including scholarships for tertiary training in statistics and procurement of statistical software.

\section{Agriculture (EUR 1.8 million)}

Ongoing support directly benefitting the agricultural sector include the development of a new strategic plan for agricultural diversification and development, strengthening health, quarantine and phyto-sanitary systems, environment watershed project as well as development of an annual agricultural review. The implementing partner of these activities is the Food and Agricultural Organisation (FAO).

Another project includes equipping the agricultural training institute, as well as developing the curricula, which will serve the delivery of programmes in agricultural training to farmers and students for St. Vincent and the Grenadines. 


\section{National Energy Action Plan (EUR 480,000)}

Following an earlier energy audit of government buildings, a project was designed to implement the recommendations of the study in selected public buildings to make them more "green" energy efficient.

\section{Improvement of education through the use of information and communication technology (EUR 12.4 million)}

The overall objective of this project is to develop human resources in VCT, through the sustainable provision of learning opportunities for all persons in the nation to equip them with the required values, skills, attitude and knowledge necessary for creating and maintaining a productive, innovative and harmonious society. The purpose of the project is to improve the quality of education at all levels nationwide by creating opportunities to use Information and Communication Technologies (ICT) in innovative ways such as integration into the pedagogy of the teaching learning processes. This will require ICT facility upgrades at the St. Vincent and the Grenadine Community College (VCTCC), the institution charged with responsibility for leading the retooling of teachers in the effective instructional use of ICT. Upgraded ICT facilities at the VCTCC will increase opportunities for vulnerable groups such as women and out-of-school youth to access high quality distance programmes locally at a reasonable contribution. This will help to empower graduates to make a much more meaningful contribution to national development.

\section{Technical Cooperation Facility (EUR 780,000)}

This allocation is destined to facilitate and strengthen the coordination and management of the EU cooperation in VCT in various respects.

\section{Support to the National Authorising Officer (EUR 780,000)}

This allocation is destined to fund the running of the operations of the official counterpart office (National Authorising Officer).

\section{Economic Diversification through Private Sector Development (EUR 5.3 million, programme completed)}

This program, which came to an end in December 2010, aimed mainly to improve access to start-up counseling, business planning, information on trade opportunities, expert and skills support to individuals with business ideas and existing small businesses (Business Gateway) with a particular focus on former banana producers and workers in the banana sector; to improve quality of the environment and services available for business through the revision of legislative and regulatory environment for private sector development; and to improve 
management and capacity to develop and implement a programme to attract foreign investment especially in rural areas and other sectors such as tourism.

\section{ICT Development Programme (EUR 4.53 million, programme completed)}

The programme, which came to an end in December 2010, aimed to contribute to further economic diversification and to improve competitiveness and employment capacity of the agricultural and other productive sectors trough creating the appropriate environment and human resource pool for the introduction of sustainable use of ICT. It had the following components: ICT, e-business strategy, leadership and awareness development; business skills development and e-business incubators; capacity-building; construction and establishment of a national ICT training and incubator facility; legislative and regulatory Framework; business-oriented e-government initiatives; and networking and experience-sharing (Regional Management Office).

Other projects are under operational closure.

\section{Sector Budget Support}

\section{Sector Budget Support on Rural Transformation (EUR 15 million, programme completed)}

This untargeted budget support programme, which came to an end in December 2010, supported the government's efforts to improve the opportunities and quality of life of the rural population, through the implementation of a sector policy framework accompanied by well-defined sectoral strategies. The program also provided direct assistance in the field of public financial management reform through CARTAC.

\section{Regional Programs}

In addition to national programmes, VCT has been benefiting from regional programmes such as the ACP Fisheries programmes, Agricultural programme, EPA implementation programme, or Carib Export programme. Nine VCT SME's received EUR 129,650 in grants awarded under the Caribbean Trade and Private Sector Development Programme (Phase 2). VCT distillers benefited from grants in the amount of EUR 122,799 under the Integrated Development Programme for the Caribbean Rum Sector.

\section{Emergency Assistance and Hurricane Tomas Assistance}

The EU is providing EUR 200,000 to restore health and sanitary conditions in St. Lucia and VCT in the aftermath of hurricane Tomas. The contribution which is being provided by the European Commission's Humanitarian Aid and Civil Protection Office (ECHO) is $45 \%$ of total eligible costs of EUR 450,000 and will be managed by the Pan American Health Organisation. The assistance goes towards interventions such as ensuring safe water supply 
in health facilities, shelters and vulnerable households; safe waste disposal, vector control activities and the reestablishment of health coverage.

In addition, STABEX funds amounting to EUR 600,000 will be used for a school furniture project, a small farmers' recovery project, and a medical supplies project.

Moreover, the EU has contributed EUR 12.5 million to the Caribbean Catastrophe Risk Insurance Facility (CCRIF). The CCRIF will provide US\$1.1 million to VCT as a result of damage sustained during the passage of Tomas.

Finally, the EU's Disaster Preparedness Programme, which commenced operations in the Caribbean in 1998, has programmed EUR 21 million towards disaster preparedness programmes with the help of NGOs, the Red Cross, UN agencies and other regional partners. The EU also contributes significantly to the Caribbean Disaster Emergency Management Agency (CDEMA).

Programmes as of January 2011

\begin{tabular}{|l|r|r|r|}
\hline \multicolumn{1}{|c|}{ Programmes as of January $\mathbf{2 0 1 1}$} & $\begin{array}{c}\text { Allocated } \\
\text { EUR }\end{array}$ & $\begin{array}{c}\text { Contracted } \\
\text { EUR }\end{array}$ & \multicolumn{1}{|c|}{$\begin{array}{c}\text { Paid } \\
\text { EUR }\end{array}$} \\
\hline Tourism and Private Sector Development programme & $8,000,000$ & $3,400,000$ & $1,500,000$ \\
\hline Agriculture & $1,800,000$ & $1,745,000$ & $1,350,000$ \\
\hline National Energy Action Plan & 480,000 & 0 \\
\hline $\begin{array}{l}\text { Improvement of education through the use of information and } \\
\text { communication technology }\end{array}$ & $12,410,000$ & $12,100,000$ & $3,000,000$ \\
\hline Technical cooperation facility & 780,000 & 104,000 & 80,000 \\
\hline Support to the NAO & 780,000 & 0 \\
\hline Economic Diversification through Private Sector Development & $5,300,000$ & 0 \\
\hline ICT Development Programme & $4,500,000$ & $4,950,000$ \\
\hline Sector Budget Support on Rural Transformation & $4,400,000$ & $4,000,000$ \\
\hline Totals & $4,000,000$ \\
\hline
\end{tabular}

Note: Regional programs and emergency assistance funding are excluded from the table. Figures are rounded up. 


\section{Appendix V. St. Vincent and the Grenadines: Statistical Issues}

\section{Assessment of Data Adequacy for Surveillance}

General: Data provision has some shortcomings, but is broadly adequate for surveillance. Statistical databases remain weak in terms of coverage, consistency, periodicity, and timeliness. While in areas central to surveillance - notably central government accounts, indicators of the financial sector and external sector accounts - the data are adequate for surveillance purposes, information on the rest of the public sector and nonbank financial intermediaries is limited. Major improvements are needed to facilitate effective surveillance, particularly in the coverage of national accounts (especially the tourism sector and related services), and on data used to monitor labor markets. Efforts to address the weaknesses in the statistical base have been hampered by low response rates to surveys (less than 50 percent) and high turnover of staff.

National Accounts: A new rebased GDP series (using 2006 as the base year instead of 1990) was released in January 2011 with assistance from CARTAC. The new series improved coverage, data sources, and methodology. The revision disaggregated some industries previously classified under government into separate sectors that now include private sector activity; these are health, education, and social development. The new series also improved the level of detail by estimating value added for business services, computer and related services, and private households with employed persons which were not accounted for in the previous series. However, some weakness remain; data on GDP broken down by expenditure is not available at constant prices, while data at current prices is not reliable due to weaknesses in estimating gross capital formation. Private final consumption expenditure is estimated as a residual. In October 2007 CARTAC also launched a project for strengthening tourism statistics in the OECS, including St. Vincent and the Grenadines. The project covers the core tourism datasets relating to visitor arrivals, visitor expenditure, tourist accommodation and statistics for other key tourism-related enterprises. The project will also seek to standardize and harmonize tourism concepts, definitions and classification schemes across these countries.

Price statistics: CPI data are reported regularly with a one-month lag. CARTAC, as part of the Fund-assisted program on Constructing Weights for the Harmonized Consumer Price Index in the ECCU has assisted in linking the 1981 based to the 2001-based CPI series. The Statistical Office is currently finalizing revision of the CPI weights with the assistance of CARTAC and the ECCB. The results are expected to be released during the first half of 2011.

Government finance statistics: Due to delays in reporting capital expenditures by some ministries, quarterly revenue and expenditure data for the central government are provided to the Fund with some lag. Discrepancies exist between the fiscal and monetary accounts, 
between above and below the line for budget data, and between financing and debt data. The financial reports of public enterprises are not timely, with about a two-year lag.

Monetary statistics: Monetary statistics are compiled and reported to the Fund by the ECCB on a monthly basis based on a standardized report form since July 2006. The institutional coverage of monetary statistics needs to be improved by including the accounts of mortgage companies, building societies, credit unions, and insurance companies. In this respect, close coordination between the ECCB and the single regulatory unit (which will supervise financial institutions other than those licensed under the Banking Act) will be crucial.

While noting some recent improvements, the 2007 data ROSC mission identified the following main shortcomings in the ECCB's monetary statistics: (i) the methodological soundness of monetary statistics can be improved by adopting internationally accepted concepts and definitions, expanding institutional coverage, and revising the classifications of financial instruments and the basis for recording; (ii) transparency can be improved, for example, by releasing monetary data to all users at the same time and strengthening the validation of the disseminated data; (iii) the timeliness of the dissemination of data on broad money and credit aggregates can be improved to meet best international practices; and (iv) the access to officially disseminated data and metadata can be improved.

Balance of payments: Balance of payments data are compiled by the ECCB on an annual basis. Data reported to STA are becoming more timely, although quality, frequency and coverage need to be improved. Quarterly estimates and the international investment position statement are not compiled. The estimates lack sufficient detail due to the unavailability of source data, and the statistical techniques used to estimates some components are weak. In particular, no estimates are available on transportation services by type or mode of transport and of travel by purpose. Further, a breakdown of portfolio and other investment by instrument or sector is not available. There is a need to compile quarterly balance of payments estimates and the annual international investment position statement; however, developing these new statistics will have to be undertaken in conjunction with the ECCB, which coordinates the compilation of the external sector statistics for all its member countries.

External debt: The Ministry of Finance maintains a database on public and publiclyguaranteed external loans that provides detailed and current information on disbursements, debt service, and debt stocks. The Treasury maintains the data on bonds placed abroad. Data from the two databases as well as information on payments by creditor (actual and scheduled) need to be further consolidated to produce timely debt stock data. 


\section{Data Standards and Quality}

St. Vincent and the Grenadines participates in the General Data Dissemination System since September 2000. The 2007 regional data ROSC on monetary statistics provides an assessment of the ECCB's monetary statistics. No data ROSC is available for other sectors.

\section{Reporting to STA (Optional)}

The International Financial Statistics page includes data on exchange rates, international liquidity, monetary statistics, prices, balance of payments, national accounts, and population. The ECCB provides the data to the IMF for publication in the Balance of Payments Yearbook. The IMF publishes annual data for the consolidated general government in the GFS Yearbook, with the 2008 edition showing annual data to 2004 . No new data have been received for more recent years. 


\section{St. Vincent and the Grenadines: Table of Common Indicators Required for Surveillance}

(As of June, 2010)

\begin{tabular}{|c|c|c|c|c|c|}
\hline & $\begin{array}{l}\text { Date of latest } \\
\text { observation }\end{array}$ & Date received $^{7}$ & $\begin{array}{l}\text { Frequency of } \\
\text { Data }^{7}\end{array}$ & $\begin{array}{l}\text { Frequency of } \\
\text { Reporting } 7\end{array}$ & $\begin{array}{l}\text { Frequency of } \\
\text { Publication }\end{array}$ \\
\hline Exchange Rates ${ }^{1}$ & Fixed Rate & NA & NA & NA & NA \\
\hline $\begin{array}{l}\text { International Reserve Assets and Reserve Liabilities of the } \\
\text { Monetary Authorities }{ }^{1,2} \text { (JGG) }\end{array}$ & November 2010 & $1 / 14 / 11$ & M & M & Q \\
\hline Reserve/Base Money (JGG) & November 2010 & $1 / 14 / 11$ & M & M & Q \\
\hline Central Bank Balance Sheet (JGG) & November 2010 & $1 / 14 / 11$ & M & M & Q \\
\hline Consolidated Balance Sheet of the Banking System (JGG) & November 2010 & $1 / 14 / 11$ & M & M & Q \\
\hline Interest Rates ${ }^{3}$ (JGG) & November 2010 & $1 / 14 / 11$ & Q & Q & Q \\
\hline Consumer Price Index & November 2010 & $1 / 14 / 11$ & M & M & M \\
\hline $\begin{array}{l}\text { Revenue, Expenditure, Balance and Composition of Financing }{ }^{4}- \\
\text { Central Government }\end{array}$ & December 2010 & $01 / 06 / 11$ & M & M & A \\
\hline $\begin{array}{l}\text { Stocks of Central Government and Central Government-Guaranteed } \\
\text { Debt }^{6}\end{array}$ & December 2010 & $01 / 10 / 11$ & M & M & A \\
\hline External Current Account Balance (SR) & 2009 & $03 / 31 / 10$ & A & A & A \\
\hline Exports and Imports of Goods and Services (SR) & 2009 & $03 / 31 / 10$ & A & A & A \\
\hline GDP/GNP & 2008 & $12 / 15 / 10$ & A & A & A \\
\hline Gross External Debt & December 2010 & $01 / 10 / 11$ & $\mathrm{M}$ & $\mathrm{M}$ & A \\
\hline
\end{tabular}

${ }^{1}$ St. Vincent and the Grenadines is a member of the Eastern Caribbean Currency Union, in which the common currency of all member states (E.C. dollar) is pegged to the U.S. dollar at $\mathrm{US} \$ 1=\mathrm{EC} \$ 2.70$.

${ }^{2}$ Includes reserve assets pledged or otherwise encumbered as well as net derivative positions.

${ }^{3}$ Both market-based and officially-determined, including discount rates, money market rates, rates on treasury bills, notes and bonds.

${ }^{4}$ Foreign, domestic bank, and domestic nonbank financing.

${ }^{5}$ The general government consists of the central government and state and local governments.

${ }^{6}$ Currency and maturity composition are provided annually.

${ }^{7}$ Daily (D), Weekly (W), Monthly (M), Quarterly (Q), Annually (A); Irregular (I); Not Available (NA); Not applicable (n.a). 


\section{IMF Executive Board Approves US\$3.26 Million Disbursement Under Rapid Credit Facility for St. Vincent and the Grenadines}

The Executive Board of the International Monetary Fund (IMF) today approved a disbursement of an amount equivalent to SDR 2.075 million (about US\$3.26 million) under the Rapid Credit Facility (RCF) for St. Vincent and the Grenadines to help the country manage the economic impact of Hurricane Tomas. The Board's approval enables the immediate disbursement of the full amount.

The late-October 2010 hurricane inflicted significant damage to agriculture, housing and infrastructure. The initial assessment conducted by the government estimated the cost of damage at 5 percent of gross domestic product. Once reconstruction is factored in, the costs are expected to be much higher. The RCF-supported program aims to address the urgent balance of payments need arising from the hurricane.

The RCF, which provides rapid financial assistance for low-income countries with an urgent balance of payments need, does not require any program-based conditionality or review. However, economic policies are expected to address the underlying balance of payments difficulties and support policy objectives including macroeconomic stability and poverty reduction. Financing under the RCF carries zero interest (until end 2011), has a grace period of $5 \frac{1}{2}$ years, and a final maturity of 10 years. The Fund reviews the level of interest rates for all concessional facilities every two years.

Following the Executive Board's discussion of St. Vincent and the Grenadines, Mr. John Lipsky, First Deputy Managing Director and Acting Chair, stated:

"St. Vincent and the Grenadines suffered significant damage to agriculture, housing, and infrastructure as a result of Hurricane Tomas in October 2010. High reconstruction and rehabilitation costs have created an immediate balance of payments need and new challenges for policymakers. 
"Because of hurricane-related spending, the fiscal deficit is expected to widen in 2011. In light of the elevated public debt, the authorities have reiterated their commitment to rely mainly on grants and concessional resources to finance the budgetary imbalance. In the event that additional grants and concessional financing do not materialize, contingency measures will be deployed to limit the deficit.

"The authorities remain committed to securing fiscal and debt sustainability over the medium-term. To this end, they have implemented fiscal reforms to facilitate the primary surpluses needed to put the debt to GDP ratio on a firmly declining path.

"The authorities are also stepping up structural reforms to ensure strong and lasting growth over the medium-term. Public finance management is being strengthened, including by enhancing the oversight of state-owned enterprises. On the financial side, legislation to establish the Single Regulatory Unit will be submitted to Parliament in the months ahead, paving the way for enhanced supervision of non-banks." 